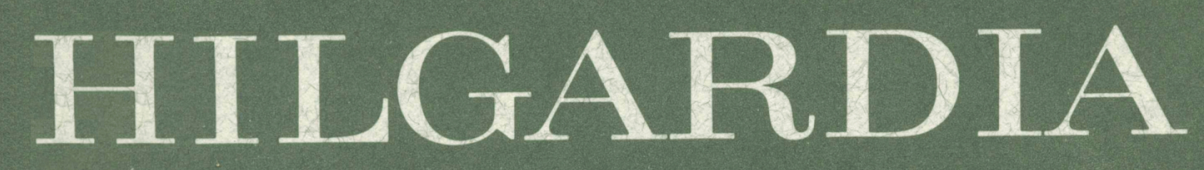

A JOURNAL OF AGRICULTURAL SCIENCE PUBLISHED BY THE CALIFORNIA AGRICULTURAL EXPERIMENT STATION

Volume 39, Number $7 \cdot$ May, 1968

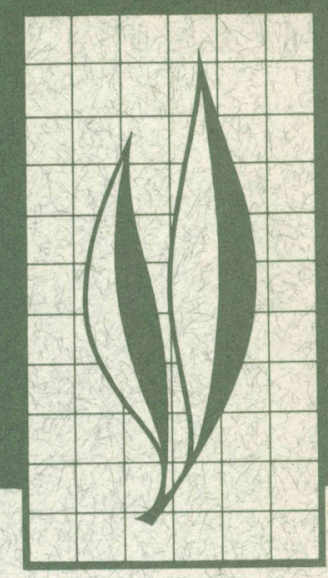

\title{
Development of Young Pear Trees with Different Rootstocks in Relation to Psylla Infestation, Pear Decline, and Leaf Curl
}

W. H. Griggs, D. D. Jensen, and Ben T. Iwakiri 


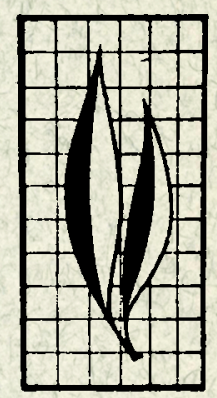

Young Bartlett, Winter Nelis, and Hardy pear Pyrus communis L. trees with six different rootstocks were studied during 1961 through 1965. Non-topgrafted trees of each type of rootstock were included. Three treatments were used: (1) saran cages placed around entire trees (caged-control); (2) spray applications (exposed-control); and (3) psylla infestation with Psylla pyricola Foerster confined to branches of trees by means of organdy sleeve cages (psylla-infested).

This study confirmed the decline tolerance of trees with Bartlett, Winter Nelis, or Pyrus calleryana Decne. seedling, or own-rooted Old Home $P$. communis rootstocks. Decline susceptibility was confirmed with trees with either $\boldsymbol{P}$, serotina Rehd. or $\boldsymbol{P}$. ussuriensis Maxim. rootstocks. Psylla-tight cages protected decline-susceptible trees-corroborating previous reports that the pear psylla is the pear decline vector.

Differences in growth among trees with decline-tolerant stocks were small. Non-topgrafted rootstock trees attained greater size than their topgrafted counterparts; their vigor was correlated with the vigor and decline tolerance each type could impart as a rootstock for $\boldsymbol{P}$. communis varieties. The size of root systems was correlated with trunk circumference and shoot growth. Tests also indicated that trees without graft unions may succumb to decline.

\section{(Continued inside back cover)}

THE AUTHORS:

W. H. Griggs is Professor of Pomology and Pomologist in the Experiment Station, Davis.

D. D. Jensen is Professor of Entomology and Entomologist in the Experiment Station, Berkeley.

Ben T. Iwakiri is Laboratory Technician IV, Department of Pomology, Davis. 


\section{Development of Young Pear Trees with Different Rootstocks in Relation to Psylla Infestation, Pear Decline, and Leaf Curl ${ }^{1}$}

\section{INTRODUCTION}

The ADvent of PEAR DECline has reemphasized the importance of rootstocks in pear culture. The virus-caused disease generally manifests itself in commercial varieties of Pyrus cummunis $\mathrm{L}$. pears that are budded or topgrafted onto certain types of rootstocks (Blodgett et al., 1963; Shalla et al., 1963, 1964; Jensen et al., 1964). The vector is the pear psylla, Psylla pyricola Foerster (Jensen et al., 1964). The susceptibility to or tolerance of the virus in a particular scion-rootstock combination apparently depends on the genetic composition of the rootstock. In susceptible combinations, the virus-infected tops cause a necrosis of sieve tubes below the bud union. This girdles the tree in various degrees of severity and causes it to decline or die (Schneider, 1959; Batjer and Schneider, 1960; Jensen et al., 1964).

Following infection, susceptible trees may develop either slow decline or quick decline (Woodbridge et al., 1957 Schneider, 1959; Batjer and Schneider, 1960; Nichols et al., 1960; Jensen et al., 1964). In trees with slow decline, terminal growth is stunted, and leaves are small and pale green. With the quickdecline syndrome, either normal-appearing or slow-decline trees suddenly wilt, and the leaves turn brown. Por. tions of the fibrous roots are killed under either type of decline. Infected trees that appear normal as well as those with slow-decline symptoms may develop early-fall red foliage.

Recently, a brown discoloration of the veins of mature leaves also has been reported to be associated with pear decline (Tsao et al., 1966).

Woodbridge et al. (1957), working in Washington and British Columbia, reported that decline occurred most frequently in trees with $P$. serotina Rehd. (P. pyrifolia Burm.) rootstocks. Batjer and Schneider (1960), working mainly in Washington, found that pear trees with $P$. serotina or $P$. ussuriensis Maxim. seedling rootstocks were highly susceptible to decline, those with imported French ( $\boldsymbol{P}$. communis) were intermediate, and those with domestic Bartlett seedling ( $P$. communis) stocks were highly resistant. Among a limited number of trees, they found decline symptoms in trees with $P$. calleryana Decne. stocks, while those with $P$. betulaefolia Bunge stocks were free of decline. They noted that scion-rooted Bartlett trees and trees with ownrooted Old Home ( $P$. communis) "trunks" did not have decline. Blodgett and Aichele (1960) also reported that Bartlett trees on their own roots were free of decline. Hartman (1962) stated that under Oregon conditions, trees

\footnotetext{
${ }^{1}$ Submitted for publication May 3, 1967.
} 
with $P$. serotina and $P$. ussuriensis rootstocks were most susceptible to decline, with $P$. serotina being far the most susceptible. He found that old trees with imported French ( $P$. communis) rootstocks planted before World War I were resistant to decline, while those with imported French rootstocks planted between World Wars I and II showed varying degrees of susceptibility. Trees with Bartlett and Winter Nelis seedling ( $P$. communis), $P$. betulaefolia seedling, and $P$. calleryana seedling stocks, and trees with self-rooted Old Home "trunkstocks" were resistant to decline. California experiments confirmed the susceptibility of trees with $P$. serotina (Griggs et al., 1962; Ryugo, 1963; Shalla et al., 1963; Gonzales et al., 1963; Jensen and Erwin, 1963; Jensen et al., 1964), and P. ussuriensis seedling rootstocks (Shalla et al., 1963) to decline. Trees with Bartlett seedling (Gonzales et al., 1963) Winter Nelis seedling (Jensen and Erwin, 1963), and $P$. calleryana seedling stocks (Jensen and Erwin, 1963), and trees with selfrooted old Home stocks (Gonzales et $a l ., 1963$ ) were resistant to decline. Selfrooted Old Home trees (Griggs and Harmann, 1960; Jensen and Erwin, 1963) also were resistant.

Blodgett et al. (1962) noted that the frequency and severity of pear decline symptoms did not vary with the scion varieties (Bartlett, Anjou, Hardy, Farmingdale, Flemish Beauty) or with the origin of budwood. On the other hand, Westwood et al. (1963) found that, with the same types of rootstocks, Bartlett was most susceptible to decline; Anjou was intermediate, and Comice was least susceptible.

Although pear decline has been associated mainly with trees with $P$. serotina, $P$. ussuriensis or imported $P$. communis rootstocks, the disease has been reported in at least a small percentage of trees with any of the commonly used rootstocks. Batjer and
Schneider (1960), Blodgett et al. (1962), and Westwood and Lombard (1966) reported decline in trees with Bartlett seedling rootstocks. Decline was reported in trees with $P$. calleryana rootstocks by Batjer and Schneider (1960), Batjer et al. (1961), Blodgett et al. (1962), and Westwood and Lombard (1966). Griggs and Hartmann (1960) and Westwood and Lombard (1966) reported decline in pear trees with quince rootstocks. Westwood and Lombard (1966) also reported declinelike symptoms in trees with Winter Nelis seedling, $P$. betulaefolia seedling, or self-rooted Old Home stocks and in self-rooted Bartlett trees.

Since most of the seed used for propagating seedling rootstocks are the result of uncontrolled pollination, there is an opportunity for hybridization. Hybrid seed resulting from the cross pollination of $P$. communis, $P$. calleryana and $P$. betulaefolia flowers with $P$. serotina or $P$. ussuriensis pollen could account for some decline susceptibility among trees with these usually decline-tolerant types of rootstocks. Catlin and Millecan (1967) emphasized the importance of knowing the identity of the pollen parent before assuming the decline tolerance of a seedling rootstock. They made chemical identification tests of the rootstocks of young pear trees with supposedlly "domestic" $P$. communis seedling rootstocks that exhibited symptoms of pear decline. The rootstocks of some of the trees proved to be pure $P$. communis, while others were identified as hybrids between $P$. communis and oriental pear species. Higher percentages of the trees with hybrid rootstocks were diagnosed as positive for pear decline by the Schneider test for phloem necrosis than for trees with pure $P$. communis stocks.

Pear growers are concerned about which of the decline-tolerant stocks should be used, particularly in old orchards where trees were lost to decline. 
In most of the California pear districts there are a number of orchards where young trees with the recommended (decline-tolerant) rootstocks have not developed satisfactorily in either new plantings or old orchards.

In addition, a relatively new disorder, "curl" (Millecan et al., 1963), which manifests itself late in the season in the foliage of mostly young trees, has further complicated the problem.
Evidently, curl is being transmitted by pear psylla, and may be associated with pear decline. The disorder is apparent throughout California's pear districts in a high percentage of young trees of all varieties. Reduced yields and vigor in affected trees have been reported.

This report summarizes a five-year study of the development of young pear trees with different rootstocks in relation to decline, psylla, and curl.

\section{MATERIALS AND METHODS}

Several types of rootstocks were planted at the University of California, Davis, during February, 1961, in a plot where mature pear trees were pulled in July, 1959. The old trees consisted of Bartlett and Winter Nelis on $P$. serotina rootstocks and were among the first in California to be stricken with pear decline. Many of them collapsed and died with typical decline symptoms during the bloom period of 1959 and for several weeks thereafter. Barnyard manure was applied to the plot during the fall and winter of 1959-1960, and a cereal crop was grown during 1960 .

The young trees were planted 6 feet apart in rows 14 feet apart with 71 to 73 trees in each row. The planting consisted of three randomized rows of $P$. serotina seedlings, two rows each of Bartlett, Winter Nelis, and $P$. calleryana seedlings, and one row each of ownrooted Old Home trees and $P$. ussuriensis seedlings. Seeds for the rootstocks were collected from open-pollinated fruit in the University orchards during 1959, stratified during the winter of 1959-1960, planted in the greenhouse in April, 1960, transplanted to the nursery in May, 1960, and dug in December, 1960. The own-rooted Old Home trees were developed from hardwood cuttings treated and callused during September and October, 1959, according to the method of Hartmann et al. (1963) and grown in the nursery during 1960.
The rootstock trees were topgrafted from 15 to 24 inches above the ground by budding during July, 1961, and whip grafting during February, 1962. In two rows of the $P$. serotina seedlings, and one row each of the Bartlett, Winter Nelis, and $P$. calleryana seedlings, a third of the trees were grafted to Bartlett, a third to Winter Nelis, and a third to Hardy. In the remaining rows, Hardy scions were omitted, and every third tree was allowed to develop without being topgrafted. All of the Bartlett and Hardy bud and scion wood was taken from one vigorous, mature tree of each variety, while the Winter Nelis propagating wood came from a number of trees.

The trees were kept under clean cultivation, were moderately pruned, and received approximately one-half pound of ammonium sulphate per tree the first year and a pound per tree annually thereafter. Irrigation was adequate, except during 1965 when reduced trunk growth indicated a shortage of soil moisture during the summer of that year. The treatments were named: exposed control, psylla infested, and caged control.

Exposed-control. The trees under exposed control were kept free of insects and mites with hand-gun spray applications. Care was taken to avoid spraying adjacent test trees. Exposed controls were subject to occasional visitation by adult psylla and, therefore, to 
possible infection with pear decline.

Psylla-infested. Psylla-infested trees were subjected to adult psylla confined on from one to four scaffold branches by means of organdy sleeve cages (fig. 1). ${ }^{2}$ Most of the psylla were obtained from commercial orchards where some of the trees were affected with pear decline. It was assumed, therefore, that they were carrying pear decline virus. However, the experiments were not designed to distinguish the effects of psylla feeding alone from those of psylla feeding combined with pear decline virus introduced by the psylla. From 50 to 100 psylla were placed in each sleeve and allowed to feed and multiply for varying periods from June 6, 1962, through September 6, 1963. Most trees were subjected to three or four months of infestation during either the 1962 or 1963 growing season. The psylla thrived within the sleeves and apparently multiplied until the foliage became limiting. The uncaged portions of these trees were kept free of insects and mites by hand spray applications.

Caged-control. The caged-control trees were protected from psylla and other insect visitation with $4 \times 4 \times 8$-foot cages covered with $32 \times 32$-inch mesh saran cloth and supported by frames made of $1 / 2$ - and $3 / 4$-inch conduit pipes (figs. 2 and 3 ). The trees were kept caged from June or July, 1962, until May, 1964.

After the psylla-feeding tests were ended, all trees in the block were given the standard sprays for insect and mite control.

Psylla populations in the surrounding blocks as well as on the exposed controls in the experimental block were sampled with sticky board traps and sweeping techniques. Eight sticky boards were maintained within the experimental block. Samplings were made at weekly intervals from March 13, 1962 , until the end of the period of sleeved psylla infestations and approximately twice each month thereafter.

During the growing seasons of 1962 and 1963, bark samples were taken at the graft union of most of the trees with psylla sleeves and from eight to 12 exposed-control trees of each type. The samples were microscopically examined for symptoms of sieve-tube necrosis according to the Schneider test (Schneider, 1959; Batjer and Schneider, 1960).

Measurements of trunk circumference and shoot length growth were made following each growing season from 1962 through 1965, and tree survival and color of foliage in the fall were recorded. In October, 1965, all surviving trees were examined for symptoms of curl. The Bartlett trees were rated according to the severity of the curl symptoms; in other trees, only the presence of curl (or its absence) was noted.

All of the trees were pulled during March, 1966, to make way for campus expansion. Photographs of vigorous specimens of the different types of trees were made before and after they were pulled.

The results of the psylla-feeding tests in relation to pear decline virus transmission to susceptible scion-rootstock combinations have been published (Jensen et al. 1964). Since the present report emphasizes the relative behavior of young pear trees with four commonly used decline-tolerant stocks, the data regarding all psylla-infested trees, regardless of the period of infestation on the tree involved, were combined for brevity.

Because of the large number of trees involved and the uniform treatment they received, the data from the exposed controls were considered best for evaluating tree performance due to the different rootstocks. These data were subjected to either analysis of variance or chi-square tests.

\footnotetext{
${ }^{2}$ See center-fold pages for all figures.
} 


\section{RESULTS AND DISCUSSION}

\section{Survival}

Survival percentages were high under all treatments for the three varieties with Bartlett seedling, Winter Nelis seedling, or $P$. calleryana seedling or own-rooted Old Home rootstocks (tables 1 , 2, and 3), confirming the decline tolerance of trees with these stocks. For any one variety, there were no significant differences in the survival rate of trees with these rootstocks, and the differences in survival among varieties were small. Most of the trees with these stocks that died did so during the first growing season. This indicated a weakness of the nursery tree or a transplanting failure, rather than susceptibility to pear decline. All except one of the few trees with these stocks that died after 1961 were dwarfish throughout their lives. The one tree, consisting of Winter Nelis on a Bartlett seedling rootstock, died during the growing season of 1965 and may have had decline, although it was not subjected to the Schneider test. A total of 45 trees, including all three varieties, with Bartlett seedling, $P$. calleryana seedling or own-rooted Old Home rootstocks were subjected to psylla infestation during 1962 and 1963. All survived until they were pulled, and all except six made relatively good growth during 1964 and 1965.

The exposed-control trees with $P$. serotina or $P$. ussuriensis seedling rootstocks had high survival rates for the first two or three years, but during 1964 and 1965, many collapsed with decline (tables 1,2 , and 3 ). This confirmed the decline susceptibility of $P$. communis varieties with these rootstocks. This correlates with observations that the sticky boards and sweeping nets revealed no psylla on the exposed controls in the plot until September 11, 1962. By September 25, 1962, a total of 31 psylla had been caught on the eight boards, and a spray was then applied to the exposed controls and uncaged portions of the trees with psylla sleeves. The boards revealed no more psylla until August, 1963, when a total of eight were caught. A spray again reduced the population to zero, according to the sticky boards, until 1964 when 11 were caught in June and five were caught in July. Then, none were caught until June, 1965. The monthly catches for June through November, 1965, were $1,5,8,11,3$, and 2 , respectively. Thus, in spite of control sprays, the exposed controls were subject to occasional psylla visitation.

Hardy trees with $P$. serotina rootstocks gave lower percentages of survival than either Bartlett or Winter Nelis trees with this rootstock.

The psylla-infested trees with $P$. serotina or $P$. ussuriensis stocks suffered earlier and greater losses to decline than similar exposed-control trees. Trees with $P$. ussuriensis rootstocks apparently were more tolerant to psylla feeding and pear decline virus than those with $P$. serotina stocks, although the numbers of trees infested were not comparable. The protection of the psylla-tight cages against pear decline for trees with these stocks was shown, since not one of the caged-control trees developed the disease until 1965-more than a year after the cages were removed. This corroborates previous reports that psylla are the pear decline vectors (Jensen et al., 1964; Gonzales et al., 1963).

Most of the exposed-control and psylla-infested trees with $P$. serotina or $P$. ussuriensis seedling rootstocks that died were diagnosed as positive for pear decline, according to the Schneider test (1959) of bud union 


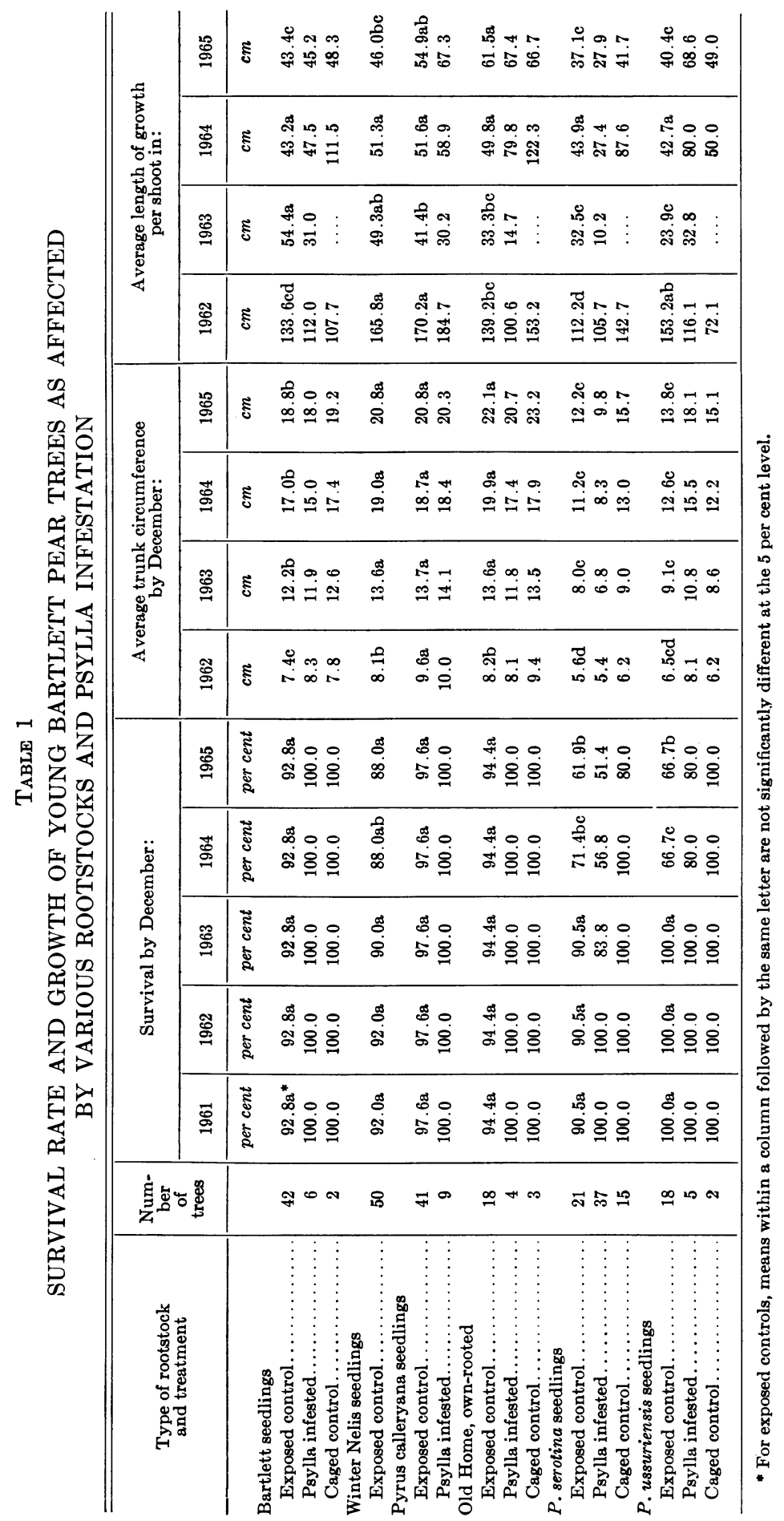




\begin{tabular}{|c|c|c|c|c|c|c|c|c|}
\hline \multirow{4}{*}{ 周 } & \multirow{4}{*}{ 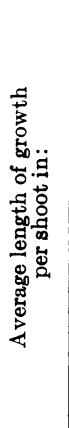 } & 总 & 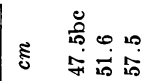 & $\begin{array}{l}\stackrel{\circ}{\infty} \\
\dot{g} \\
\dot{q}\end{array}$ & 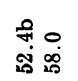 & 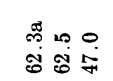 & 总 & 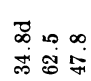 \\
\hline & & 莕 & है & 苞 & 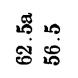 & 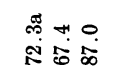 & 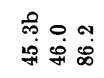 & 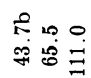 \\
\hline & & $\stackrel{\mathscr{g}}{\mathrm{g}}$ & 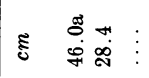 & 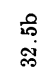 & 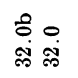 & 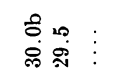 & 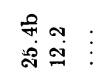 & 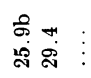 \\
\hline & & $\stackrel{\mathscr{\Xi}}{\leftrightarrows}$ & 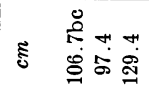 & 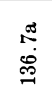 & 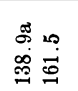 & 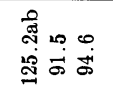 & 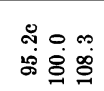 & 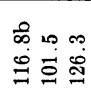 \\
\hline 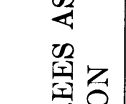 & 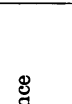 & $\stackrel{8}{\circ}$ & 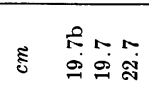 & 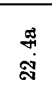 & 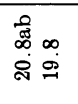 & 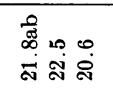 & 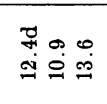 & $\begin{array}{l}\stackrel{\leftrightarrow}{\infty} \infty \\
\stackrel{\infty}{\infty} \stackrel{\infty}{\infty}\end{array}$ \\
\hline 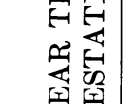 & 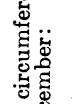 & 芯 & 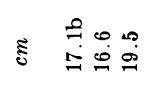 & $\begin{array}{l}\underset{\infty}{\infty} \\
\stackrel{\infty}{\infty}\end{array}$ & 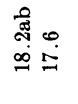 & 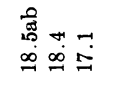 & 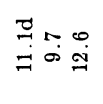 & 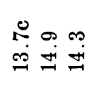 \\
\hline 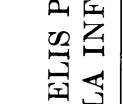 & 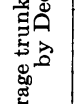 & 兽 & 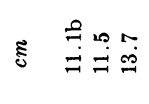 & 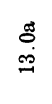 & 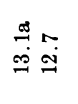 & 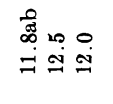 & 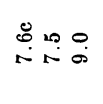 & 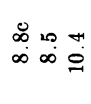 \\
\hline 受运 & $\frac{\pi}{4}$ & 禺 & \begin{tabular}{l}
0 \\
\hdashline \\
0
\end{tabular} & $\begin{array}{l}8 \\
\dot{0} \\
\infty\end{array}$ & $\stackrel{\substack{\pi \\
\infty}}{\infty}$ & 英 & 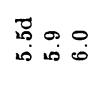 & 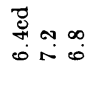 \\
\hline 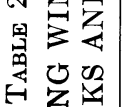 & & 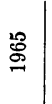 & 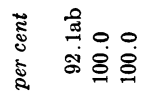 & 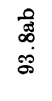 & 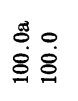 & 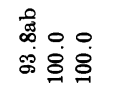 & $\begin{array}{l}8 \\
8 \\
8\end{array}$ & 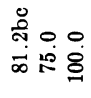 \\
\hline 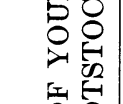 & 总 & 芯 & 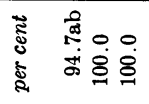 & 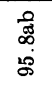 & 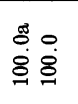 & 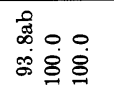 & 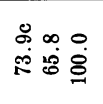 & 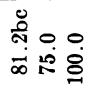 \\
\hline 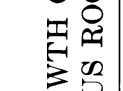 & 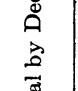 & ஜ & 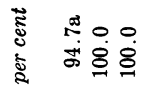 & 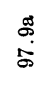 & $\begin{array}{l}\text { s̊ } \\
8 \\
8\end{array}$ & 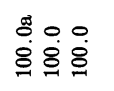 & 递 & 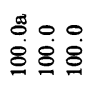 \\
\hline 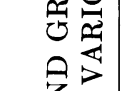 & 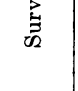 & 听 & 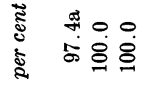 & 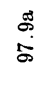 & $\begin{array}{l}\stackrel{8}{\circ} 0 \\
\dot{8}\end{array}$ & 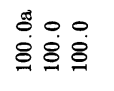 & 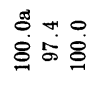 & 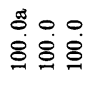 \\
\hline 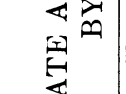 & & $\vec{\Phi}$ & 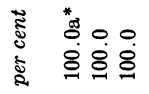 & $\begin{array}{l}\stackrel{8}{8} \\
\stackrel{8}{\Delta}\end{array}$ & 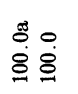 & 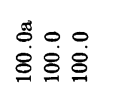 & 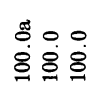 & 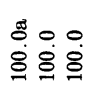 \\
\hline 岁 & 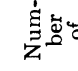 & & $\infty$ & $\stackrel{\infty}{\sim}$ & 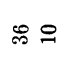 & $\mathscr{\theta} \pi$ & $\approx \infty$ & $\varphi \pi$ \\
\hline 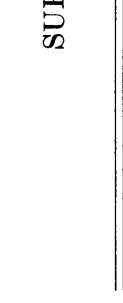 & 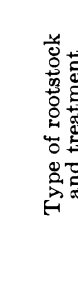 & & 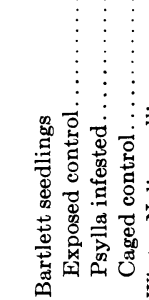 & & 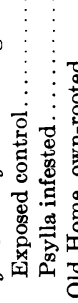 & 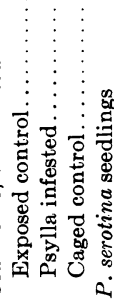 & 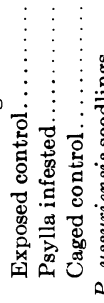 & 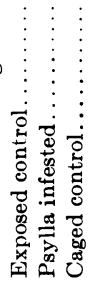 \\
\hline
\end{tabular}




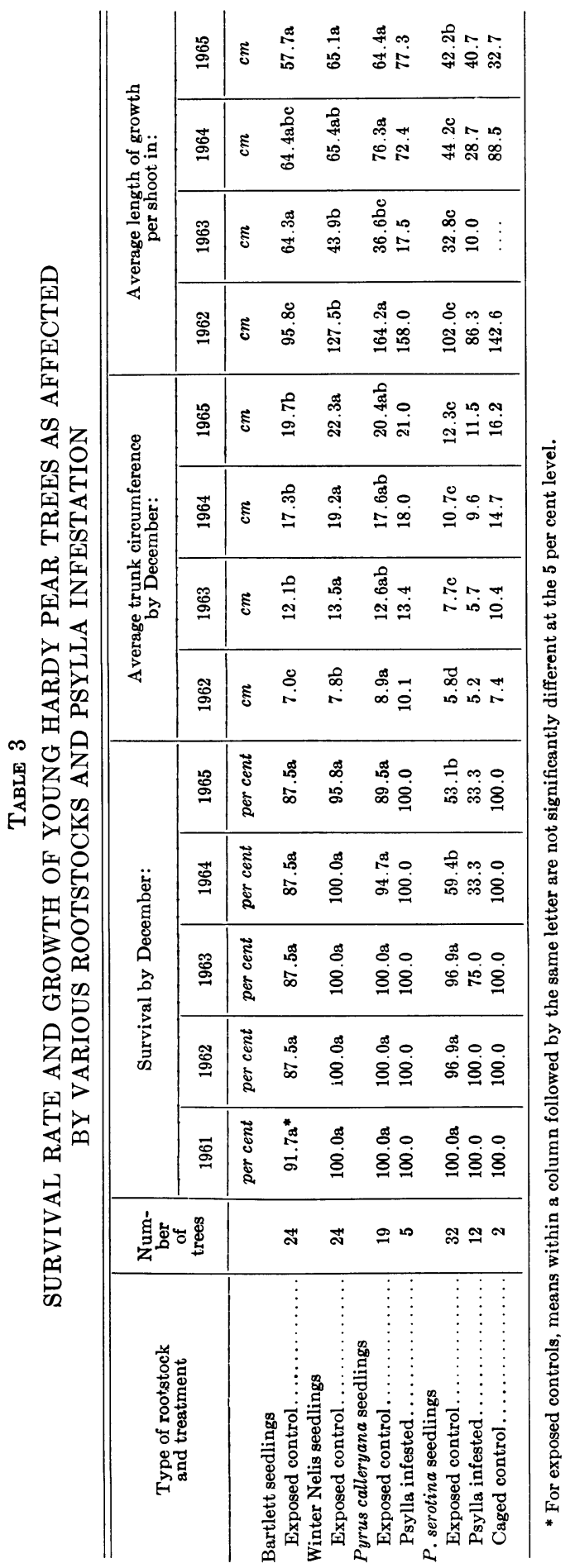


bark samples collected during 1962 and 1963. On the other hand, most of the representative trees of all types that survived these treatments until they were pulled were diagnosed as normal. Comparative bud union samples from the caged-control trees also showed no symptoms of decline.

All of the Bartlett and Winter Nelis seedlings that were allowed to grow without being topgrafted lived through the experiment (table 4). Three Bartlett seedlings apparently were unharmed by psylla in three sleeves per tree from September 5, 1962, until January 22, 1963. Non-topgrafted $P$. calleryana seedlings and own-rooted old Home stock also gave high percentages of survival in both the exposed-control and psylla-infested trees.

Survival was not as high for the nontopgrafted $P$. serotina and $P$. ussuriensis seedlings. Five of the 17 exposedcontrol P. serotina seedlings died. Three of these were dwarfed from the time of transplanting and died during 1962. The other two made average growth until they collapsed, one in 1964 and the other in 1965, with decline-like symptoms. Since the trees had no graft unions, the Schneider test was not used for diagnosis. When subjected to psylla infestation during 1962, two of the six non-topgrafted $P$. serotina trees collapsed during 1964, and another showed severe symptoms of decline during the fall of 1965. This verified the decline susceptibility of these trees and added further evidence that trees without graft unions may succumb to decline. The loss of the three non-topgrafted $P$. ussuriensis seedling trees under exposed control probably was due to causes other than decline, since they failed to make appreciable growth from the time of transplanting. The three psylla-infested $P$. ussuriensis seedlings apparently were unharmed by the treatment.

In commercial orchards, vigorous $P$. serotina and $P$. ussuriensis seedling trees are occasionally seen in blocks where the surrounding trees were devastated by decline. Such trees usually developed from rootstock suckers after the $P$. communis scion variety was killed by the blight organism, Erwinia amylovora Burr. or some other cause. Oriental pear varieties, developed from $P$. serotina and $P$. ussuriensis also have shown resistance to decline when topgrafted on $P$. serotina, $P$. ussuriensis, and $P$. communis seedlings or quince, Cydonia oblonga L. rootstocks. Such trees are relatively free of pear psylla, indicating the insect's preference for the foliage of varieties of $P$. communis. Ryugo (1963) examined 885 mature pear trees consisting of reciprocal scionrootstock combinations of $P$. communis seedlings and either $P$. serotina or $P$. ussuriensis clones. He found that only 1 per cent of the oriental clones on their own roots or grafted onto seedlings of $P$. communis had declined, while 50 per cent of the Bartlett trees and 28 per cent of the Hardy trees with the same oriental clones as rootstocks had succumbed to the disease. In the present study, the non-topgrafted $P$. serotina and $P$. ussuriensis seedling trees also showed greater resistance to decline than commercial varieties of $\boldsymbol{P}$. communis topgrafted on $P$. serotina and $P$. ussuriensis seedlings. The percentages of losses of the young, nontopgrafted seedling trees were greater than those obtained by Ryugo (1963).

Another example of pear decline in trees without graft unions was the collapse during 1960 through 1965 of a number of own-rooted "Variolosa" trees, propagated from cuttings taken from a mother tree designated as $P$. variolosa Wallich, in the University orchard at Davis. The susceptibility of the seedling and own-rooted trees to decline virus is not explainable on the same basis as for the susceptibility of grafted trees with root systems that are 


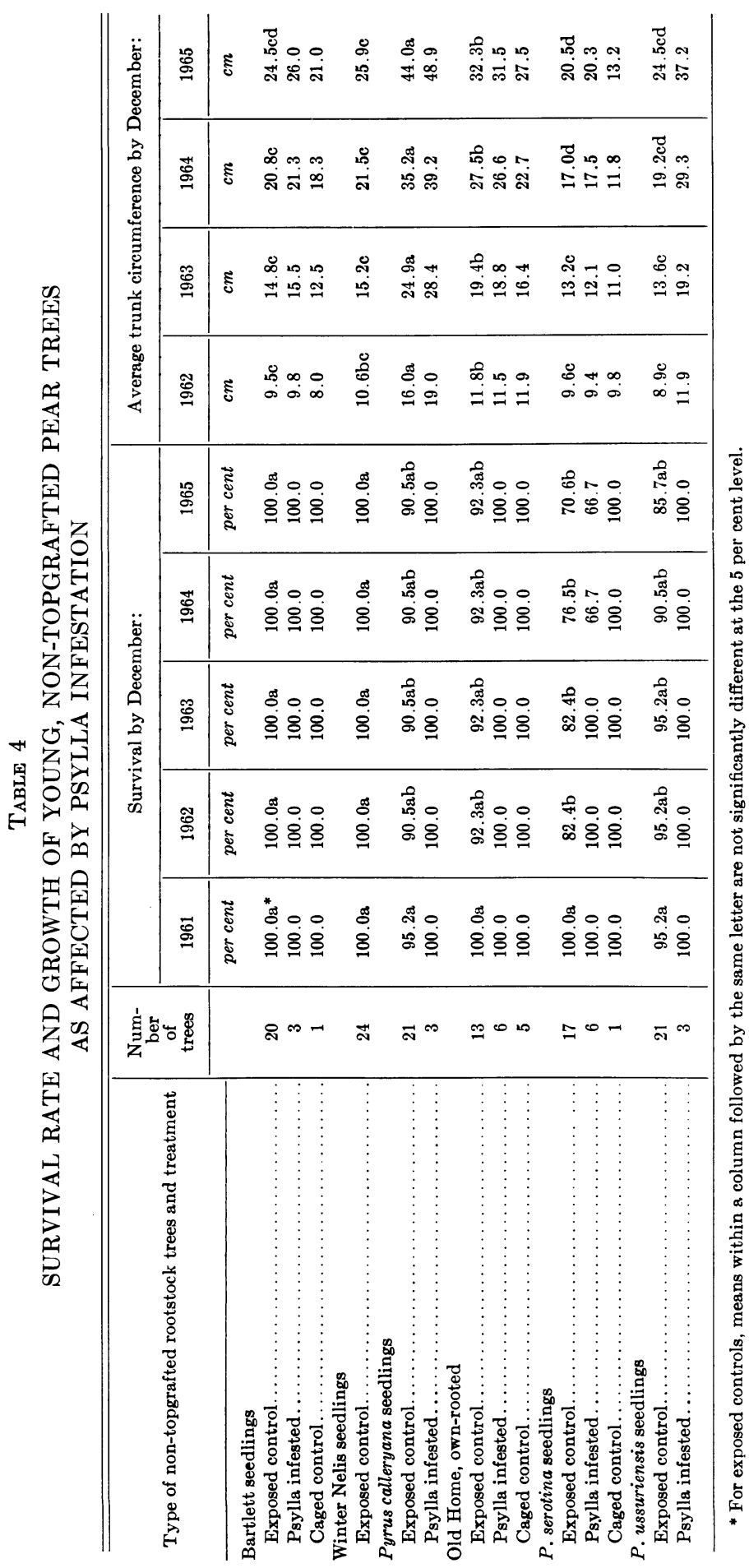


genetically different from their tops. Until recently, the scion variety was considered tolerant of pear decline virus; specific symptoms had not been observed. When inoculated with pear decline virus under greenhouse conditions, however, brown vein symptoms were reported in own-rooted Variolosa trees that were propagated from cut- tings taken from trees at Davis (Tsao et al., 1966). They were also found in Variolosa trees with $P$. ussuriensis rootstocks and in both seedling and grafted clones of $P$. communis. This substantiated the susceptibility of certain types of own-rooted trees to pear decline virus and showed that the disease may injure scion tissues directly.

\section{Trunk and Shoot Growth}

\section{Bartlett trees}

In December, 1962, the mean trunk circumference of the exposed-control trees consisting of Bartlett on $P$. calleryana rootstocks was significantly larger than those of Bartlett on any of the other rootstocks (table 1). Following the 1963, 1964, and 1965 growing seasons, however, there were no significant differences between the trunk circumferences of Bartlett trees with Old Home, $P$. calleryana, or Winter Nelis seedling rootstocks (figs. 5, 6, and 7). Trees with these rootstocks had significantly larger trunks than Bartletts on Bartlett seedlings. Based on the annual increments, however, the trees with Bartlett seedling stocks made about as much trunk growth as those with Winter Nelis or $\boldsymbol{P}$. calleryana seedling stocks. Evidently the Bartlett seedlings were smaller at the time they were topgrafted, and this disadvantage persisted throughout the duration of the experiment. The mean trunk circumferences of Bartletts on $P$. serotina or $P$. ussuriensis were not significantly different during these years, but were significantly smaller than those of Bartlett on Bartlett seedlings (figs. 4, 8, and $9)$. All types of the Bartlett trees made less average growth in trunk circumference during 1965 than during the two previous years, presumably due to inadequate irrigation.

The greater initial vigor of trees with $P$. calleryana rootstocks should give them an advantage as replants in old orchards where shade and root competi- tion from surrounding trees inhibit the development of young trees.

Reimer (1925) noted that Bartlett, Old Home, Anjou, Bose, Comice, Howell, and Winter Nelis grew vigorously on $P$. calleryana rootstocks. On the other hand, Tukey and Brase (1933) reported that young Bartlett, Anjou, Seckel, and Kieffer trees with $P$. calleryana seedling rootstocks made relatively poor growth. Day (1947) reported that Bartlett budded directly to $P$. calleryana seedlings did not grow vigorously. Westwood and Lombard (1966) reported that five-year-old Bartlett, Anjou, Bosc, Comice, Seckel, Packham's Triumph, and Eldorado trees with $P$. calleryana stocks were approximately the same size as comparable trees with several other rootstocks, including Bartlett and Winter Nelis seedlings and own-rooted Old Home.

The contradictory performances of commercial pear varieties with $P$. calleryana seedling rootstocks may be due to genetic variation, since $P$. calleryana seeds are collected from many different seedling trees under open pollination. This points up the need for reliable seed from controlled pollinations for $P$. calleryana as well as other types of seedling rootstocks. Seedlings from $P$. communis varieties, such as Bartlett and Winter Nelis, are potentially less variable than $P$. calleryana seedlings, however, since at least the pistillate parent is constant.

The average length of growth per shoot for all types of Bartlett trees in 
1962 was relatively great, since only a few shoots developed from the scions during the first growing season after topgrafting (table 1). During 1963 the trees that made the most growth in trunk circumference tended to make the most shoot growth. However, trees with Bartlett seedling stocks made more shoot growth, and those with Old Home stocks made less shoot growth than their trunk growth would indicate. This same tendency occurred in 1964, although the differences between the amounts of shoot growth were not significant. Shoot and trunk circumference growth were highly correlated in 1965 , even though the increments of trunk growth for all of the Bartlett trees were less than half that made during 1963 and 1964. It is interesting that even though growth in trunk circumference was greatly reduced, the amount of shoot growth made by the different types of trees during 1965 was about the same as or greater than that made during 1964. Shoot length growth of Bartlett pears normally is completed before July 10 at Davis, but growth from the cambium which results in increased branch and trunk circumference continues later in the summer. Evidently, soil moisture became limiting in July, 1965-too late to appreciably affect shoot length, but in time to check growth in trunk circumference.

Bartlett trees with any rootstocks, except $P$. ussuriensis seedlings, that were infested with psylla during 1962 and 1963, showed a marked reduction in shoot growth during 1963 (table 1). Growth of trunk circumference was reduced during 1963 and 1964 on trees with Bartlett seedling or own-rooted Old Home rootstocks; this was also true for surviving Bartletts on $P$. serotina seedlings for the duration of the experiment. The psylla were removed from the trees by September 6, 1963, and trees with any of the rootstocks except $P$. serotina responded with good growth during 1964 and 1965.
The caged-control trees made about the same amount or more growth than the exposed controls. Although they had the advantage of being entirely free of psylla during most of the 1962 and all of the 1963 seasons, they were growing under reduced light and had to be cut back several times during 1963 to keep them within the cages. The cages were removed during May, 1964, and all trees except those with $P$. ussuriensis rootstocks made about twice as much or more growth during 1964 than comparable exposed controls. During 1965, the trees that had been caged made about the same amount of shoot growth as the exposed-control treesindicating that the increased growth in 1964 was due largely to heavy cutbacks in 1963 .

\section{Winter Nelis trees}

Based on the mean trunk circumferences of the exposed controls at the end of the 1962 growing season, $P$. calleryana seedlings were the most vigorous rootstocks for the Winter Nelis variety (table 2). Following the next three growing seasons, however, there were no significant differences between the mean trunk circumferences of these trees or those with Winter Nelis seedling or own-rooted Old Home stocks. Winter Nelis trees with Bartlett seedling stocks had consistently smaller trunk circumferences than those with the $P$. calleryana or Winter Nelis seedling or own-rooted Old Home stocks the smaller diameters of the Bartlett seedling nursery trees, since the trees with these stocks made about as much annual growth in trunk circumference as those with Winter Nelis or $P$. calleryana seedling or Old Home stocks. Trees with $P$. serotina or $P$. ussuriensis seedling rootstocks were significantly smaller in trunk circumference at the end of the last three growing seasons than those with any of the other four stocks.

Trees that made the greatest in- 
creases in trunk circumference also showed greater shoot growth. The maximum trunk and shoot growth was made in 1964. During 1965 the mean increase in trunk circumference for the Winter Nelis trees with any of the six rootstocks was approximately half of that made in 1964, while shoot growth ranged from 71 to 86 per cent of that made in 1964. Reduced growth probably was due to inadequate irrigation during the summer of 1965 , as it was for the Bartlett trees.

Psylla infestation caused no appreciable reduction in trunk growth of any of the Winter Nelis trees, except those with $P$. serotina rootstocks. Psylla evidently were responsible for the reduced shoot growth made in 1963 of trees with either Bartlett or $\boldsymbol{P}$. serotina seedling rootstocks. After the psylla sleeves were removed, these trees made about as much shoot growth as the exposed controls.

The caged-control Winter Nelis trees made about the same annual increments of trunk growth as the exposed controls. Following the removal of the cages, they made more shoot growth than the exposed controls, undoubtedly because they were kept cut back while caged.

\section{Hardy trees}

By the end of 1962, the exposed-control Hardy trees with $P$. calleryana rootstocks were significantly larger in trunk circumference and had made greater shoot growth than those with the other types of rootstocks (table 3 ). At the end of the next three growing seasons, however, the trunk circumferences of the trees with $P$. calleryana roots were intermediate between those with Winter Nelis and those with Bartlett seedling rootstocks. Throughout the experiment, trees with Winter Nelis were significantly larger in trunk circumference than those with Bartlett seedling stocks. Trees with Bartlett seedling rootstocks made more shoot growth during 1963 than those with Winter Nelis or P. calleryana seedling stocks. During 1964 and 1965, however, there were no significant differences in shoot growth made by trees with these three rootstocks. The trees with $P$. serotina rootstocks made significantly less growth in trunk circumference and shoot length than those with the decline-resistant stocks.

The positive correlation between growth in trunk diameter and shoot length, noted above for Bartlett and Winter Nelis trees, also was apparent with the Hardy trees. Also, the amount of trunk growth made by the Hardy trees during 1965 was much less than that made in 1964, while shoot growth was only slightly reduced.

Psylla infestation during 1963 apparently had no effect on the trunk growth of Hardy trees with $P$. calleryana rootstocks, but reduced their shoot growth during 1963 to less than half of that made by the exposed controls. After the psylla were removed, these trees made vigorous shoot growth in both 1964 and 1965. The psylla or the virus they transmitted inhibited both trunk and shoot growth of the trees with $P$. serotina stocks that were not killed.

The caged-control trees with $P$. serotina rootstocks were more vigorous than the psylla-infested or exposed-control trees. Their reduced shoot growth during 1965 indicated that they became infected with pear decline after the cages were removed.

\section{Non-topgrafted trees}

All exposed-control non-topgrafted trees grew more rapidly than their topgrafted counterparts (table 4 ). The $P$. calleryana seedlings showed outstanding vigor (fig. 10), and by the end of the 1963 growing season, their mean trunk circumference was larger than that attained by any of the topgrafted trees at the end of 1965. The ownrooted Old Home trees also showed 
great vigor (fig. 11). Their trunk circumferences were significantly smaller than those of the $P$. calleryana seedling trees, but they were significantly larger than the other types. Winter Nelis, Bartlett, $P$. ussuriensis, and $P$. serotina seedlings followed in order of mean size of trunk. The differences in trunk size among Winter Nelis, Bartlett, and $P$. ussuriensis seedlings and between $P$. serotina and $P$. ussuriensis seedlings were not significant, however.

Psylla infestation had no appreciable effect on the growth of the non-topgrafted trees as compared to exposedcontrol and caged-control as indicated by trunk growth. The smaller size of the caged-control trees undoubtedly was due to the heavy pruning necessary to keep them confined within the cages.

Vigor of the non-topgrafted rootstock trees was apparently correlated with the amount of vigor and degree of pear decline tolerance they could impart when serving as rootstocks for $P$. communis varieties. This relationship was limited, however. The non-topgrafted $P$. calleryana seedling trees were remarkably vigorous. However, when grafted with Bartlett, Winter Nelis, and Hardy, they were not significantly more vigorous than comparable trees with either Winter Nelis seedling or own-rooted Old Home rootstocks-after an initial period of rapid growth. A study of the trunk circumferences of the individual non-topgrafted rootstock trees represented in table 4 emphasizes the role of vigor in the pear decline tolerance of the rootstock. The $22 P$. calleryana seedlings and the 23 own-rooted Old Home trees were uniformly vigorous, and by December, 1965, not one of them had a trunk circumference less than threefourths of the mean circumference shown in the table. Only oue of the 24 Winter Nelis and two of the 24 Bartlett seedling trees had trunk circumferences less than three-fourths of the means. In contrast, five of the $21 P$. ussuriensis trees and two of the surviving $17 P$. serotina trees had trunk circumferences less than three-fourths of the means. The $P$. serotina trees were in a class of their own since they were uniformly small. A few of the $P$. ussuriensis seedling trees were very vigorous and, when pulled, were as large as the $P$. calleryana trees (fig. 15). The inherent vigor of a portion of the $P$. ussuriensis trees would account for the resistance to psylla infestation and pear decline noted in some of the Bartlett and Winter Nelis trees with this type of rootstock; it would also explain why mature trees with $P$. ussuriensis rootstocks have shown greater resistance to pear decline than those with $P$. serotina stocks.

\section{Root Systems}

The root systems of the trees were examined when they were pulled during March, 1966. Comparative evaluations were difficult because many of the roots were broken off, particularly the more horizontally growing ones. In general, the largest and most vigorous trees had the most extensive root systems. Trunk circumference at the time the trees were pulled gave a better indication of the size of the root system than the amount of shoot growth made during the final growing season. Since only healthy trees were selected for photographing before and after pulling, the photographs of trees and roots of Bartlett on $P$. serotina and $P$. ussuriensis rootstocks represent the most vigorous of the surviving trees.

\section{Bartlett trees}

Based on the final trunk circumference and shoot growth made during 1965 (table 1), Bartlett trees with ownrooted Old Home rootstocks were largest and those with $P$. calleryama, Win- 
ter Nelis, Bartlett, $P$. ussuriensis, and $P$. serotina seedling stocks followed in order of decreasing size. The average size of the root systems followed the same order, with the exception that the $P$. calleryana roots appeared to be more extensive than those of Old Home (figs. 6 and 7). Part of the difference probably was due to less breakage of the $P$. calleryana roots. The root systems of the trees with Old Home rootstocks were considerably more uniform in size than those of trees with any of the seedling stocks. There was little if any difference in the range of size of the root systems between trees with Winter Nelis or $P$. calleryana seedling stocks. Root systems of trees with Bartlett seedling stocks averaged smaller and were more variable in size than those of trees with Old Home, $P$. calleryana, or Winter Nelis seedling rootstocks (figs. 4, 5, 6 and 7).

There was little difference in the range or average size of the root systems of Bartlett trees with either $P$. ussuriensis or $P$. serotina seedling rootstocks. Both types were considerably smaller and less uniform than those of the other types of rootstocks. Figure 8 shows one of the largest root systems of Bartlett on $P$. serotina and figure 9 shows the largest root system of any Bartlett with $P$. ussuriensis roots.

Psylla infestation apparently had little or no effect on the size of the root systems of any of the surviving Bartlett trees, except those with $P$. serotina rootstocks. These were reduced in proportion to the stunting of the aboveground portion of the trees as shown by the smaller trunk circumferences (table $1)$.

\section{Winter Nelis trees}

The size of the root systems of the Winter Nelis trees obviously was correlated with the final trunk size and shoot growth made in 1965 (table 2). There was little difference in the aver- age size of the root systems of the trees with Winter Nelis or P. calleryana seedling or Old Home rootstocks. Individual trees with either Winter Nelis or $P$. calleryana seedling rootstocks developed larger root systems than any of those with Old Home stocks, but the Old Home root systems were more uniform in size. The root systems of the trees with Winter Nelis seedling rootstocks were somewhat larger and more spreading than those of trees with Bartlett seedling stocks. They were also more uniform in size than those of trees with either Bartlett seedling or P. calleryana rootstocks.

The size of the root systems of Winter Nelis trees with $P$. ussuriensis stocks varied from small and weak to the largest for any Winter Nelis tree in the experiment. The average size, however, was below that of any of the other types except $P$. serotina. None of the Winter Nelis trees with $P$. serotina rootstocks had large root systems, and the average size was below that of any of the other types of rootstocks.

The root systems of Winter Nelis trees with $P$. serotina rootstocks that survived psylla infestation were somewhat smaller than their exposed controls. Similar psylla infestation apparently did not reduce the final size of the root systems of trees with the other types of rootstocks.

\section{Hardy trees}

The size of the root systems of the Hardy trees were closely correlated to the tree size and vigor as indicated by the trunk circumference and length of shoot growth made in 1965 (table 3). Hardy trees with Winter Nelis seedling rootstocks developed larger and more uniform root systems than trees with either $P$. calleryana or Bartlett seedling stocks. The root systems of the trees with Bartlett seedling stocks were less spreading than those with Winter Nelis or $P$. calleryana rootstocks. A few trees 
with $P$. calleryana stocks had larger root systems than any of the trees with Bartlett seedling stocks, but others were considerably smaller than the smallest root systems of the Bartlett seedlings. The mean size of the two types was about the same.

Hardy trees with $P$. serotina seedling rootstocks had the smallest and most variable root systems. The largest root system of this type was smaller than the average size for trees with Bartlett, Winter Nelis or $P$. calleryana rootstocks.

The root systems of the five Hardy trees with $P$. calleryana seedling rootstocks exposed to psylla sleeves during 1963 were as large as those of the exposed controls of this type when pulled. Also, the four trees with $P$. serotina rootstocks that survived psylla infestation had root systems about equal to their exposed controls.

\section{Non-topgrafted trees}

Each type of non-topgrafted rootstock tree produced larger root systems than trees consisting of this type of rootstock topgrafted with a commercial variety.

$\boldsymbol{P}$. calleryana seedlings produced the largest and most uniform root systems as well as the largest and most uniform trees (fig. 10, table 4). The root systems of these trees were about twice as large on the average as the largest root systems produced by the Bartlett, Winter Nelis, and Hardy trees with $P$. calleryana seedling rootstocks. When topgrafted, therefore, the $P$. calleryana seedlings were able to impart only a portion of their potential vigor to the scion variety.

Trees exposed to psylla infestation with sleeve cages during 1962 had root systems as large as those of the exposed controls when pulled.

Old Home tree root systems, developed from rooted cuttings, ranked second in average size among the non-top- grafted trees and were somewhat larger than those of their topgrafted counterparts (compare figs. 7 and 11). Although the root systems of the Old Home trees were not nearly as large as those of the $P$. calleryana seedlings, they imparted as much or more vigor as $P$. calleryana to the resulting trees when topgrafted.

No evidence of damage and no appreciable differences were apparent between the final sizes of the root systems of the psylla-infested Old Home trees and those of the exposed controls.

Root systems developed from cuttings generally are considered less desirable than those produced by seedlings, because the roots tend to arise from the same plane at the base of the cutting and grow more horizontally than seedling roots (fig. 12). The ownrooted Old Home trees or rootstocks overcome these weaknesses, however, by the branching of the original ring of roots (figs. 7 and 11) and by the production of adventitious roots above the original roots after transplanting (fig. 13). The size, uniformity, and vigor of the Bartlett and Winter Nelis trees with own-rooted Old Home rootstocks (tables 1 and 2) as well as the non-topgrafted Old Home trees (table 4) prove the excellence of this type of root system.

Winter Nelis seedlings produced root systems that were smaller and not as uniform as those of the Old Home trees. They were larger than those of Bartlett, Winter Nelis, and Hardy trees with Winter Nelis seedling rootstocks, however, and more uniform in size than the root systems of Bartlett trees with Winter Nelis seedling rootstocks. When topgrafted, they imparted as much or more vigor to the root systems of the resulting trees as any of the other rootstocks.

Bartlett seedling root systems, due to greater uniformity, were about the same average size as those of the Win- 
ter Nelis seedlings. They averaged larger and were more uniform in size than those of trees consisting of Bartlett, Winter Nelis, or Hardy on Bartlett seedling rootstocks. When used as a rootstock for Bartlett, the Bartlett seedlings did not impart as much vigor as Old Home, Winter Nelis seedlings, or $P$. calleryana seedlings. They also failed to impart as much vigor as Winter Nelis seedlings, when used as a rootstock for Hardy and Winter Nelis.

The root systems of the psylla-infested Bartlett seedlings were as large as those of the exposed controls.

$P$. ussuriensis seedling root systems were smaller on the average than those of Old Home trees and about the same size as those of the Winter Nelis and Bartlett seedlings, although a few of the $P$. ussuriensis seedling trees had nearly as large root systems as the $P$. calleryana seedlings (fig. 15). They averaged considerably larger than those of Bartlett or Winter Nelis trees with $P$. ussuriensis seedling stocks, however, and not one of the Bartlett or Winter Nelis trees with this rootstock produced a root system more than half the size of those developed by the most vigorous non-topgrafted $P$. ussuriensis seedlings.

The root systems of the three $P$. ussuriensis seedling trees exposed to psylla infestation during 1962 evidently were not damaged since they were larger than the average for the exposed controls.

$P$. serotina seedling root systems were smaller on the average than those of the other types of non-topgrafted trees, but larger than those of Bartlett (fig. 8), Winter Nelis, or Hardy trees with $P$. serotina seedling rootstocks. The root systems of the more vigorous of the surviving $P$. serotina seedling trees (fig. 14) compared favorably in size with those of the other types of non-topgrafted trees except $P$. calleryana seedlings and the most vigorous $P$. ussuriensis seedlings. When the $P$. serotina seedlings were topgrafted with Bartlett, Winter Nelis, or Hardy, however, the root systems of the resulting trees were smaller than those of any of the other stock-scion combinations.

The root systems of the four surviving psylla-infested $P$. serotina seedlings were about the same size as those of the exposed controls.

\section{Foliage Color}

Vigorous pear trees in the major California districts usually remain green until during November. If no frost occurs, the leaves gradually drop during November and December. A portion of the leaves turn yellow before abscission, but about as many are still green when they fall. A frost greatly increases the rate of drop and causes more yellowing and some reddening of the leaves. Red foliage before the occurrence of a frost usually indicates a weakness or disorder.

Blodgett et al., (1962), working with young pear trees with different rootstocks in Washington, reported that a high percentage of trees showing severe reddening of foliage by October 9,1959 , expressed slow decline symptoms the following year. Trees that remained green or showed slight reddening by this date showed a lesser tendency to slow decline in 1960. Millecan et al. (1963) reviewed the factors associated with early fall red coloration of pear foliage and emphasized its relation to pear decline, leaf curl, and field mouse damage.

The roots of the trees used in the present experiments were examined when they were pulled. Since hardly any rodent damage was noted, it was concluded that most of the early fall red foliage was due to psylla feeding, pear decline virus, leaf curl, or, possibly, nitrogen deficiency. The data re- 
TABLE 5

COLOR OF FALL FOLIAGE AND LEAF CURL OF YOUNG BARTLETT PEAR TREES AS AFFECTED BY VARIOUS ROOTSTOCKS AND PSYLLA INFESTATION

\begin{tabular}{|c|c|c|c|c|c|c|c|c|}
\hline \multirow[b]{2}{*}{ Type of rootstock and treatment } & \multicolumn{3}{|c|}{ October, 1963} & \multicolumn{5}{|c|}{ October, 1965} \\
\hline & $\begin{array}{c}\text { Num- } \\
\text { ber } \\
\text { of } \\
\text { trees }\end{array}$ & $\begin{array}{c}\text { Trees } \\
\text { with } \\
\text { some red } \\
\text { leaves }\end{array}$ & $\begin{array}{l}\text { Average } \\
\text { red leaf } \\
\text { rating* }\end{array}$ & $\begin{array}{l}\text { Number } \\
\text { of trees }\end{array}$ & $\begin{array}{c}\text { Trees } \\
\text { with } \\
\text { some red } \\
\text { leaves }\end{array}$ & $\begin{array}{l}\text { Average } \\
\text { red leaf } \\
\text { rating* }\end{array}$ & $\begin{array}{l}\text { Trees } \\
\text { with leaf } \\
\text { "curl" }\end{array}$ & $\begin{array}{c}\text { Average } \\
\text { leaf } \\
\text { "curl" } \\
\text { rating } \dagger\end{array}$ \\
\hline Bartlett seedlings & & per cent & & & per cent & & per cent & \\
\hline Exposed control $\ldots \ldots \ldots \ldots \ldots$ & 39 & $28.2 \mathrm{~b} \ddagger$ & $0.5 \mathrm{~b}$ & 39 & $56.4 \mathrm{ab}$ & $0.7 \mathrm{a}$ & $84.6 \mathrm{~b}$ & 2.0abc \\
\hline Psylla infested................. & 6 & 100.0 & 1.8 & 6 & 66.7 & 0.9 & 83.3 & 2.2 \\
\hline Caged control $\ldots \ldots \ldots \ldots \ldots \ldots$ & 2 & 0.0 & 0.0 & 2 & 50.0 & 0.5 & 100.0 & 20 \\
\hline Winter Nelis seedlings & & & & & & & & \\
\hline $\begin{array}{l}\text { Exposed control .......... } \\
\text { Pyrus calleryana seedlings }\end{array}$ & 45 & $40.0 \mathrm{~b}$ & $0.6 \mathrm{~b}$ & 45 & $64.4 \mathrm{a}$ & $0.8 \mathrm{a}$ & $95.6 \mathrm{ab}$ & $2.1 \mathrm{ab}$ \\
\hline Exposed control......... & 40 & $45.0 \mathrm{~b}$ & $0.6 \mathrm{~b}$ & 40 & $37.5 b$ & $0.5 \mathrm{a}$ & $97.5 \mathrm{ab}$ & $1.9 \mathrm{bc}$ \\
\hline Psylla infested . . . . . . . . & 9 & 77.8 & 1.3 & 9 & 33.3 & 0.3 & 88.9 & 2.1 \\
\hline Old Home, own-rooted & & & & & & & & \\
\hline Exposed control......... & 17 & $29.4 \mathrm{~b}$ & $0.3 \mathrm{~b}$ & 17 & $29.4 \mathrm{~b}$ & $0.3 \mathrm{a}$ & $100.0 \mathrm{a}$ & $2.5 \mathrm{a}$ \\
\hline Psylla infested . . . . . . . . . . . & 4 & 75.0 & 1.0 & 4 & 0.0 & 0.0 & 75.0 & 1.1 \\
\hline Caged control $\ldots \ldots \ldots \ldots \ldots \ldots \ldots$ & 3 & 0.0 & 0.0 & 3 & 0.0 & 0.0 & 33.3 & 0.3 \\
\hline$P$. serotina seedlings & & & & & & & & \\
\hline Exposed control........ & 19 & $52.6 \mathrm{~b}$ & $1.3 \mathrm{a}$ & 13 & $46.2 \mathrm{ab}$ & $0.9 \mathrm{a}$ & $84.6 \mathrm{~b}$ & $1.5 \mathrm{~cd}$ \\
\hline Psylla infested............. & 31 & 93.5 & 2.2 & 19 & 73.7 & 1.3 & 42.1 & 0.5 \\
\hline 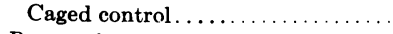 & 15 & 40.0 & 05 & 12 & 16.7 & 0.4 & 66.7 & 0.7 \\
\hline P. ussuriensis seedlings & & & & & & & & \\
\hline Exposed control...... & 18 & $83.3 \mathrm{a}$ & $1.3 \mathrm{a}$ & 12 & $50.0 \mathrm{ab}$ & $0.8 \mathrm{a}$ & $83.3 \mathrm{~b}$ & $1.2 \mathrm{~d}$ \\
\hline Psylla infested................. & 5 & 80.0 & 1.2 & 4 & 50.0 & 0.8 & 100.0 & 1.7 \\
\hline Caged control $\ldots \ldots \ldots \ldots \ldots \ldots$ & 2 & 0.0 & 0.0 & 2 & 0.0 & 0.0 & 500 & 0.5 \\
\hline
\end{tabular}

* Red leaf rating: $0=$ leaves green; $1=1$ to 25 per cent red leaves; $2=25$ to 50 per cent red leaves; $3=50$ to 100 per cent red leaves.

$\dagger$ Leaf curl rating: $0=$ no curl; $1=1$ to 25 per cent of leaves affected; $2=25$ to 50 per cent of leaves affected; $3=50$ to 100 per cent of leaves affected.

$\ddagger$ For exposed controls, means within a column followed by the same letter are not significantly different at the 5 per cent level.

garding color of foliage, presented in tables 5 through 8 , were compiled from ratings made October 29, 1963, and October 25,1965 . The minimum air temperature recorded by a thermograph near the experimental block during the fall periods prior to October 29, 1963, and October 25,1965 , was $42^{\circ} \mathrm{F}$ for both years. Hence, frost did not influence the color of foliage (the data for which are shown in the tables).

\section{Bartlett trees}

Regardless of treatment or type of rootstock, the most vigorous Bartlett trees tended to show the least red foliage (table 5). By October, 1963, the exposed-control Bartlett trees with $P$. serotina and $P$. ussuriensis rootstocks showed significantly more red foliage than those with any of the other stocks.
There were no significant differences in the amount of red foliage between Bartlett trees with the other stocks. By October, 1965, Bartletts on Bartlett or Winter Nelis seedlings showed more red foliage than in 1963, while those on $P$. calleryana showed less, and those on Old Home showed the same. This emphasized the relationship between vigor and red foliage (table 1). The exposedcontrol trees with $P$. serotina or $P$. ussuriensis stocks showed less red foliage than in 1963, undoubtedly because the weakest trees on these stocks had died of decline.

Following psylla infestation with sleeve cages during 1962 and 1963, Bartlett trees with all types of rootstocks except $P$. ussuriensis showed more red foliage by fall, 1963 , than the exposed controls. As measured by red 
TABLE 6

COLOR OF FALL FOLIAGE AND LEAF CURL ON YOUNG WINTER NELIS PEAR TREES AS AFFECTED BY VARIOUS ROOTSTOCKS AND PSYLLA INFESTATION

\begin{tabular}{|c|c|c|c|c|c|c|c|}
\hline \multirow[b]{2}{*}{$\begin{array}{c}\text { Type of rootstock } \\
\text { and treatment }\end{array}$} & \multicolumn{3}{|c|}{ October, 1963} & \multicolumn{4}{|c|}{ October, 1965} \\
\hline & $\begin{array}{c}\text { Number } \\
\text { of trees }\end{array}$ & $\begin{array}{c}\text { Trees with } \\
\text { some red } \\
\text { leaves }\end{array}$ & $\begin{array}{l}\text { Average } \\
\text { red leaf } \\
\text { rating* }\end{array}$ & $\begin{array}{c}\text { Number } \\
\text { of trees }\end{array}$ & $\begin{array}{l}\text { Trees with } \\
\text { some red } \\
\text { leaves }\end{array}$ & $\begin{array}{l}\text { Average } \\
\text { red leaf } \\
\text { rating* }\end{array}$ & $\begin{array}{l}\text { Trees with } \\
\text { leaf "curl" }\end{array}$ \\
\hline \multicolumn{7}{|l|}{ Bartlett seedlings } & per cent \\
\hline Exposed control.... & 36 & $16.7 \mathrm{c} \dagger$ & $0.4 \mathrm{c}$ & 35 & $71.4 \mathrm{a}$ & $1.1 \mathrm{ab}$ & $85.7 \mathrm{a}$ \\
\hline Psylla infested...... & 7 & 100.0 & 2.3 & 7 & 100.0 & 1.1 & 100.0 \\
\hline Caged control $\ldots \ldots \ldots \ldots \ldots \ldots$ & 3 & 0.0 & 0.0 & 3 & 66.7 & 1.0 & 100.0 \\
\hline \multicolumn{8}{|l|}{ Winter Nelis seedlings } \\
\hline Exposed control .............. & 47 & $40.4 \mathrm{~b}$ & $0.9 \mathrm{~b}$ & 45 & $73.3 \mathrm{a}$ & $0.9 \mathrm{~b}$ & $88.9 \mathrm{a}$ \\
\hline \multicolumn{8}{|l|}{ Pyrus calleryana seedlings } \\
\hline Exposed control......... & 36 & $33.3 \mathrm{bc}$ & $0.8 \mathrm{bc}$ & 36 & $33.3 \mathrm{~b}$ & $0.6 \mathrm{~b}$ & $83.3 \mathrm{a}$ \\
\hline Psylla infested . ............. & 10 & 60.0 & 1.5 & 10 & 60.0 & 0.7 & 80.0 \\
\hline \multicolumn{8}{|l|}{ Old Home, own-rooted } \\
\hline Exposed control...... & 16 & $81.2 \mathrm{a}$ & $1.3 \mathrm{ab}$ & 15 & $80.0 \mathrm{a}$ & $0.9 \mathrm{~b}$ & $100.0 \mathrm{a}$ \\
\hline Psylla infested ....... & 4 & 1000 & 1.0 & 4 & 25.0 & 0.2 & 100.0 \\
\hline Caged control.......... & 4 & 0.0 & 0.0 & 4 & 0.0 & 0.0 & 50.0 \\
\hline \multicolumn{8}{|l|}{$P$. serotina seedlings } \\
\hline Exposed control..... & 23 & $56.5 \mathrm{ab}$ & $1.1 \mathrm{ab}$ & 14 & $64.3 \mathrm{a}$ & $1.8 \mathrm{a}$ & $28.6 \mathrm{~b}$ \\
\hline Psylla infested...... & 34 & 94.1 & 2.3 & 22 & 63.6 & 1.5 & 36.4 \\
\hline Caged control $\ldots \ldots \ldots \ldots \ldots \ldots$ & 10 & 10.0 & 0.1 & 8 & 37.5 & 0.9 & 75.0 \\
\hline \multicolumn{8}{|l|}{ P. ussuriensis seedlings } \\
\hline Exposed control........ & 16 & $68.8 \mathrm{a}$ & $1.4 \mathrm{a}$ & 13 & $46.2 \mathrm{ab}$ & $1.0 \mathrm{~b}$ & $46.2 \mathrm{~b}$ \\
\hline Psylla infested . . . . . . . . . & 4 & 75.0 & 2.2 & 3 & 0.0 & 0.0 & 100.0 \\
\hline Caged control $\ldots \ldots \ldots \ldots \ldots \ldots$ & 4 & 0.0 & 0.0 & 4 & 50.0 & 0.8 & 50.0 \\
\hline
\end{tabular}

* Red leaf rating: $0=$ leaves green; $1=1$ to 25 per cent red leaves; $2=25$ to 50 per cent red leaves; $3=50$ to 100 per cent red leaves.

$\dagger$ For exposed controls, means within a column followed by the same letter are not significantly different, at the 5 per cent level.

TABLE 7

COLOR OF FALL FOLIAGE AND LEAF CURL ON YOUNG HARDY PEAR TREES AS AFFECTED BY VARIOUS ROOTSTOCKS AND PSYLLA INFESTATION

\begin{tabular}{|c|c|c|c|c|c|c|c|}
\hline \multirow[b]{2}{*}{$\begin{array}{l}\text { Type of rootstock } \\
\text { and treatment }\end{array}$} & \multicolumn{3}{|c|}{ October, 1963} & \multicolumn{4}{|c|}{ October, 1965} \\
\hline & $\begin{array}{c}\text { Number } \\
\text { of trees }\end{array}$ & $\begin{array}{l}\text { Trees with } \\
\text { some red } \\
\text { leaves }\end{array}$ & $\begin{array}{l}\text { Average } \\
\text { red leaf } \\
\text { rating* }\end{array}$ & $\begin{array}{l}\text { Number } \\
\text { of trees }\end{array}$ & $\begin{array}{l}\text { Trees with } \\
\text { some red } \\
\text { leaves }\end{array}$ & $\begin{array}{l}\text { Average } \\
\text { red leaf } \\
\text { rating* }\end{array}$ & $\begin{array}{l}\text { Trees with } \\
\text { leaf "curl" }\end{array}$ \\
\hline & & per cent & & & per cent & & per cent \\
\hline Exposed control..... & 21 & $28.6 \mathrm{~b} \dagger$ & $0.4 \mathrm{~b}$ & 21 & $57.1 \mathrm{a}$ & $0.8 \mathrm{a}$ & $100.0 \mathrm{a}$ \\
\hline Winter Nelis seedlings & & & & & & & \\
\hline $\begin{array}{l}\text { Exposed control................. } \\
\text { Pyrus calleryana seedlings }\end{array}$ & 24 & $79.2 \mathrm{a}$ & $1.3 \mathrm{a}$ & 23 & $65.2 \mathrm{a}$ & $1.1 \mathrm{a}$ & $91.3 \mathrm{a}$ \\
\hline 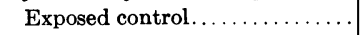 & 19 & $73.7 \mathrm{a}$ & $1.2 \mathrm{a}$ & 17 & $82.4 \mathrm{a}$ & $1.2 \mathrm{a}$ & $100.0 \mathrm{a}$ \\
\hline Psylla infested.$\ldots \ldots \ldots \ldots \ldots$ & $\mathbf{5}$ & 100.0 & 2.2 & 5 & 80.0 & 1.2 & 100.0 \\
\hline$P$. serotina seedlings & & & & & & & \\
\hline Exposed control............. & 31 & $74.2 \mathrm{a}$ & $1.4 \mathrm{a}$ & 17 & $70.6 \mathrm{a}$ & $1.2 \mathrm{a}$ & $64.7 \mathrm{~b}$ \\
\hline Psylla infested ............. & 9 & 100.0 & 3.0 & 4 & 50.0 & 1.1 & 75.0 \\
\hline Caged control $\ldots \ldots \ldots \ldots \ldots \ldots$ & 2 & 0.0 & 0.0 & 2 & 50.0 & 0.5 & 100.0 \\
\hline
\end{tabular}

${ }^{*}$ Red leaf rating: $0=$ leaves green; $1=1$ to 25 per cent red leaves; $2=25$ to 50 per cent red leaves; $3=50$ to 100 per cent red leaves.

$\dagger$ For exposed controls, means within a column followed by the same letter are not significantly different, at the 5 per cent level. 
TABLE 8

COLOR OF FALL FOLIAGE AND LEAF CURL ON YOUNG, NON-TOPGRAFTED PEAR TREES AS AFFECTED BY PSYLLA INFESTATION

\begin{tabular}{|c|c|c|c|c|c|c|c|}
\hline \multirow[b]{2}{*}{$\begin{array}{l}\text { Type of non-topgrafted root- } \\
\text { stock trees and treatment }\end{array}$} & \multicolumn{3}{|c|}{ October, 1963} & \multicolumn{4}{|c|}{ October, 1965} \\
\hline & $\begin{array}{l}\text { Number } \\
\text { of trees }\end{array}$ & $\begin{array}{l}\text { Trees with } \\
\text { some red } \\
\text { leaves }\end{array}$ & $\begin{array}{c}\text { Average } \\
\text { red leaf } \\
\text { rating* }\end{array}$ & $\begin{array}{l}\text { Number } \\
\text { of trees }\end{array}$ & $\begin{array}{l}\text { Trees with } \\
\text { some red } \\
\text { leaves }\end{array}$ & $\begin{array}{l}\text { Average } \\
\text { red leaf } \\
\text { rating* }\end{array}$ & $\begin{array}{l}\text { Trees with } \\
\text { leaf "curl" }\end{array}$ \\
\hline Bartlett seedlings & & per cent & & & per cent & & per cent \\
\hline Exposed control. & 20 & $20.0 \mathrm{~b} \dagger$ & $0.4 \mathrm{bc}$ & 20 & $65.0 \mathrm{a}$ & $0.8 \mathrm{ab}$ & $85.0 \mathrm{a}$ \\
\hline Psylla infested ........ & 3 & 100.0 & 2.0 & 3 & 66.7 & 1.0 & 100.0 \\
\hline Caged control................ & 1 & 0.0 & 0.0 & 1 & 100.0 & 1.0 & 100.0 \\
\hline $\begin{array}{l}\text { Winter Nelis seedlings } \\
\text { Exposed control. }\end{array}$ & 24 & $667 \mathrm{~g}$ & 169 & & & & \\
\hline Pyrus calleryana seedlings & 24 & & $1.6 \mathrm{a}$ & 24 & $41.7 \mathrm{a}$ & $0.5 \mathrm{~b}$ & $75.0 \mathrm{a}$ \\
\hline Exposed control.......... & 19 & $5.3 \mathrm{~b}$ & $0.1 \mathrm{c}$ & 19 & $0.0 \mathrm{~b}$ & $0.0 \mathrm{c}$ & $0.0 \mathrm{~b}$ \\
\hline Psylla infested $\ldots \ldots \ldots \ldots$ & 3 & 33.3 & 0.3 & 3 & 0.0 & 0.0 & 0.0 \\
\hline Old Home, own-rooted & & & & & & & \\
\hline Exposed control. ..... & 12 & $66.7 \mathrm{a}$ & $0.9 \mathrm{ab}$ & 12 & $50.0 \mathrm{a}$ & $0.5 \mathrm{~b}$ & $100.0 \mathrm{a}$ \\
\hline Psylla infested ...... & 6 & 100.0 & 1.2 & 6 & 33.3 & 0.3 & 100.0 \\
\hline Caged control........ & $\mathbf{5}$ & 0.0 & 0.0 & $\mathbf{5}$ & 0.0 & 0.0 & 80.0 \\
\hline$P$. serotina seedlings & & & & & & & \\
\hline Exposed control.... & 14 & $50.0 \mathrm{a}$ & $1.1 \mathrm{ab}$ & 12 & $66.7 \mathrm{a}$ & $0.8 \mathrm{ab}$ & $16.7 \mathrm{~b}$ \\
\hline Psylla infested ....... & 6 & 66.7 & 1.7 & 4 & 50.0 & 1.0 & 00 \\
\hline Caged control ......... & 1 & 0.0 & 0.0 & 1 & 0.0 & 00 & 0.0 \\
\hline P. ussuriensis seedlings & & & & & & & \\
\hline Exposed control ...... & 20 & $40.0 \mathrm{a}$ & $1.0 \mathrm{ab}$ & 18 & $66.7 \mathrm{a}$ & $11 \mathrm{a}$ & $11.1 \mathrm{~b}$ \\
\hline Psylla infested . . . & 3 & 33.3 & 0.7 & 3 & 33.3 & 0.3 & 0.0 \\
\hline
\end{tabular}

* Red leaf rating: $0=$ leaves green; $1=1$ to 25 per cent red leaves; $2=25$ to 50 per cent red leaves; $3=50$ to 100 per cent red leaves.

$\dagger$ For exposed controls, means within a column followed by the same letter are not significantly different at the 5 per cent level.

foliage, Bartletts on Bartlett seedlings were about as sensitive to psylla feeding (or psylla feeding and pear decline virus) as Bartletts on $P$. serotina. By October, 1965, all surviving Bartlett trees previously infested with psylla showed less red foliage than they had in 1963. Increased vigor following the removal of the psylla sleeves clearly was correlated with Bartletts on the decline-resistant stocks. Part of the "improvement" of the trees with $P$. serotina or $P$. ussuriensis stocks, however, could be accounted for by the death of trees susceptible to decline.

Except for a few Bartlett trees with $P$. serotina rootstocks, the caged-control trees showed no early fall red coloration in 1963. Although the sticky boards revealed very few psylla in the experimental plot during the 1963 growing season, only the caged controls were completely protected from psylla visitation. This emphasizes the role of psylla feeding (or psylla feeding and pear decline virus) as a cause of early fall red foliage and indicates that a very light infestation can cause some reddening. Since the cages were removed early in 1964, the caged-control trees were exposed to possible psylla visitation during the growing seasons of 1964 and 1965. One of the two previously caged Bartletts on Bartlett seedlings showed some red leaves, but those on Old Home and P. ussuriensis did not. Three of the 15 previously caged Bartletts on $P$. serotina died of decline during the summer of 1965, but the surviving trees showed only a small amount of red foliage. Although the psylla population in the plot was very small during 1964 and 1965, obviously there were enough to transmit pear de- 
cline virus to these three trees which had remained healthy so long as they were protected by psylla-tight cages.

\section{Winter Nelis trees}

The exposed-control Winter Nelis trees with Bartlett seedling rootstocks showed significantly less red foliage in October, 1963 (table 6), than comparable trees with any of the other rootstocks except $P$. calleryana. The large amount of red foliage exhibited by Winter Nelis on Old Home is interesting, since these trees made relatively good growth in 1963 (table 2), and the Bartlett trees with this stock did not show as much red foliage (table 5). By October, 1965, the exposed-control trees with Bartlett, Winter Nelis, and $P$. serotina seedling stocks showed more red foliage than they had in 1963 . Trees with the other types of stocks showed about the same amount or a little less. The Winter Nelis trees with Bartlett, Winter Nelis, Old Home, and P. serotina stocks had considerably more red foliage in October, 1965, than Bartlett trees with these stocks (compare tables 5 and 6). Perhaps the Winter Nelis variety is somewhat more sensitive to psylla feeding than Bartlett.

Although the Winter Nelis trees making the least growth generally had the most red foliage, the relationship between vigor and red foliage was not as consistent as in the Bartlett trees.

All of the Winter Nelis trees infested with psylla in 1962 and 1963 showed more red foliage in 1963 than the exposed controls. The red leaf rating for Winter Nelis on Bartlett seedlings was as high as for Winter Nelis on $P$. serotina - which emphasizes again the sensitivity of trees with Bartlett seedling stocks to heavy psylla feeding. Although the Winter Nelis trees previously subjected to psylla feeding had lower red leaf ratings in October, 1965, than in 1963, most of them had more red foliage than comparable Bartlett trees (compare tables 5 and 6 ). It appears that the Winter Nelis trees either have less capacity for recovery from heavy psylla infestation, or they are more sensitive to the occasional feeding during psylla population increases that occurred during 1964 and 1965. Again, part of the "improvement" in foliage color of trees with $P$. serotina and $P$. ussuriensis stocks could be accounted for by the death and removal of the more decline-susceptible trees.

With the exception of one Winter Nelis tree with a $P$. serotina seedling rootstock, all of the caged controls remained summer-green during October, 1963. By October, 1965, all of the previously caged-control trees except those with old Home stocks had more red foliage than comparable Bartlett trees (compare tables 5 and 6). Evidently the buildup in the psylla population during August and September, 1965, was responsible for most of the red foliage; and Winter Nelis may be more attractive to psylla than Bartlett-or more sensitive to their feeding.

\section{Hardy trees}

The relationship between red foliage and shoot growth also was evident for the Hardy trees. The exposed-control Hardy on Bartlett seedlings made significantly more shoot growth during 1963 and showed significantly less red foliage in October of that year than Hardy trees with other stocks (tables 3 and 7). Hardy trees with either Winter Nelis or $P$. calleryana seedling stocks had considerably more red foliage in October, 1963, than comparable Bartlett and Winter Nelis on these stocks (compare tables 5, 6, and 7). The October, 1965, evaluations, however, revealed no significant differences in the amount of red foliage between the Hardy trees with the different stocks. Also, there were no significant differences in the amount of shoot growth made in 1965 by Hardy trees with 
Bartlett, Winter Nelis, and $P$. calleryana seedling stocks (table 3 ). Although the Hardy trees with $P$. calleryana stocks made good shoot growth in 1965 , they showed considerably more red foliage than Bartlett and Winter Nelis trees with this stock.

Only Hardy trees with $P$. calleryana or $P$. serotina seedling stocks were psylla-infested during 1962 and 1963, but the sensitivity of these trees to psylla feeding (or psylla feeding and pear decline virus) was shown by their high red leaf ratings in October, 1963 (table 7). By October, 1965, the trees showed less red foliage than they had in 1963. They also made much more growth in 1965 (table 3). A good portion of the "improvement" of the trees with $P$. serotina stocks, as shown in the table, could be accounted for by the death of decline-susceptible trees.

The two caged-control Hardy trees with $P$. serotina stocks were free of red foliage in October, 1963, indicating the benefit of keeping the variety completely free of psylla visitation. Following the removal of the cages, one of the trees showed some red foliage in October, 1965.

\section{Non-topgrafted trees}

During October, 1963, the Bartlett and $P$. calleryana seedlings showed less red foliage under exposed control than the other types of rootstock trees (table 8 ). The $P$. calleryana seedlings had less red foliage than the commercial varieties topgrafted on $P$. calleryana (compare tables 5, 6, 7, and 8). The Bartlett seedlings had about the same amount of red foliage as the three varieties with Bartlett seedling stocks. The Winter Nelis seedlings had higher red leaf ratings than Bartlett and Winter Nelis trees with Winter Nelis seedling stocks. The non-topgrafted Old Home trees showed more red foliage than Bartlett on Old Home, but less than
Winter Nelis on Old Home. By October, 1965, the Bartlett and $P$. ussuriensis seedlings had somewhat more, while the other rootstocks trees had somewhat less red foliage than they had in 1963 . The Winter Nelis and $P$. calleryana seedlings showed less red foliage than trees consisting of commercial varieties topgrafted on these rootstocks. The amount of red foliage on the other types of rootstock trees was not consistently different from that noted on their topgrafted counterparts.

The differences in trunk growth made during 1963 and 1965 are not correlated with the above differences in red foliage between the two years (tables 4 and 8). Also, the differences in foliage color between the non-topgrafted rootstocks trees and their topgrafted counterparts are not closely associated with amounts of trunk growth. Between types of rootstock trees, however, the fastest growing ones, such as $P$. calleryana, had less red foliage than the slower growing ones, such as $P$. serotina.

With the exception of the $P$. ussuriensis seedlings, all of the psylla-infested rootstock trees had more red foliage in October, 1963, than the exposed controls; but only the $P$. serotina trees showed reduced trunk growth under the treatment (table 8). By October, 1965 , all of the trees showed less red foliage than they had in 1963 , indicating recovery after removal of the psylla sleeves. The Bartlett and $P$. serotina seedlings showed less improvement than the other types of rootstock trees, however, and two of the six $P$. serotina trees had died-apparently from pear decline. All of the trees except the $P$. serotina seedlings made as much trunk growth or more than did the exposed controls in 1965.

The caged-control trees, completely protected from psylla visitation, developed no red foliage by October, 1963, emphasizing again the role of psylla feeding in the development of red foli- 
age. After removal of the cages, the Bartlett tree developed red foliage, but the $P$. serotina and Old Home trees had no red foliage during October, 1965.

It has been assumed that early fall red foliage associated with pear decline is a nonspecific symptom resulting from girdling brought about by a necrosis of phlcem sieve tubes below the bud union in susceptible scion-stock combinations (Blodgett et al., 1962; Millecan et al., 1963; Tsao et al., 1966). Jensen et al. (1964) compared the fall color of foliage of young $P$. communis varieties on $P$. serotina rootstocks subjected to viruliferous psylla or virusfree psylla during the summer of 1963 with that of psylla-free controls. By November, 1963, 47.6 per cent of the trees receiving viruliferous psylla showed red foliage, while 33.3 per cent of the tree receiving virus-free psylla and 4.3 per cent of the psylla-free controls had red foliage. In the present experiments infestation with psylla transferred from trees with slow decline caused red foliage in decline-tolerant scion-stock combinations as well as decline-susceptible ones. The non-topgrafted trees, with the exception of the $P$. calleryana seedlings, also developed red foliage in roughly the same proportions as their topgrafted counterparts. It appears, therefore, that girdling may or may not be a prerequisite for red foliage. Red foliage, therefore, may indicate damage from psylla feeding alone or psylla feeding plus pear decline virus for non-topgrafted trees and decline-tolerant scion-stock combinations as well as decline-susceptible ones.

\section{Leaf Curl}

"Curl" was named and described by Millecan et al. (1963) as a condition which appears late in the season mostly on young and, occasionally, on old pear trees. Varying portions of the leaves on affected trees change from green to reddish-purple, are undulated, and curled downward with the leaf tip sometimes touching the lower surface. Graft union samples, which they collected from affected trees and subjected to the Schneider test, indicated to them that curl is not related to pear decline. They tentatively concluded that the curl disorder is caused by a graft- and seed-transmitted virus.

During July, 1964, G. H. Kaloostian ${ }^{3}$ (personal communication of December 13, 1966) infested trees, consisting of Bartlett on $P$. ussuriensis or Bartlett on $P$. communis seedling rootstocks, with psylla collected from decline-infected trees. No visible symptoms were observed in 1964, but during August, 1965, the Bartletts on $P$. ussuriensis showed decline symptoms, while those on $P$. communis showed leaf curl. The trees that developed leaf curl made very little growth in 1966, and the leaf symptoms again developed as in 1965 . He tentatively suggested that leaf curl is caused by a strain of the pear decline virus.

In the present experiments most of the leaves showing curl symptoms were located on vigorous shoots. Affected leaves were often thickened, and many remained green or showed bronzing rather than reddish purple. A portion of the curled leaves dropped from two to three weeks before the normal ones. Curl symptoms are shown in figures 16 and 17.

\section{Bartlett trees}

High percentages of all the exposedcontrol Bartlett trees showed leaf curl symptoms in October, 1965 (table 5). Bartletts on $P$. serotina or $P$. ussuriensis stocks showed less curl, however,

\footnotetext{
${ }^{3}$ G. H. Kaloostian is Research Entomologist, U. S. Department of Agriculture, Entomology Research Division, University of California, Riverside.
} 
than Bartlett trees with the other types of stocks. Since trees with the oriental stocks generally were less vigorous than the others (table 1), this suggested a correlation between tree vigor and curl. Only six of the 39 exposed-control trees with Bartlett seedling rootstocks were free of curl symptoms (table 5). The detailed data, not shown, revealed that these trees had smaller average trunk circumference and made only about half as much shoot growth in 1965 as the average for the treatment (table 1). For the 33 trees that showed curl, six made poor growth. Only two of the 45 trees with Winter Nelis seedling rootstocks were free of curl; one was vigorous, the other, weak. For the remaining 43 trees with curl, two made poor growth. Only one of the 40 Bartlett trees with $P$. calleryana stocks was free of curl, and it made relatively poor growth. In contrast, two of the remaining 39 trees with curl symptoms made poor growth. All of the exposed-control Bartlett trees with old Home stocks showed curl, and all made vigorous growth in 1965. The exposed-control Bartletts on $P$. serotina and $P$. ussuriensis stocks that showed no curl symptoms also were low in vigor as compared with those showing curl.

Thus, most of the exposed-control Bartlett trees with curl symptoms made relatively good growth in 1965, while most of those with no curl made poor growth. Since, as pointed out above, the least vigorous trees generally had the most red foliage, an inverse relationship between curl and red foliage would be expected. Trees with the least curl did tend to show the most red foliage, but some types of trees showing high percentages of curl also showed high percentages of red foliage (table $5)$. This inconsistency probably was due to the reddish-purple foliage associated with curl. Hence, curl could account for part of the red foliage in the vigorous trees, while psylla feeding or pear de- cline accounted for most of the red foliage in the stunted ones.

Following psylla infestation, high percentages of all Bartlett trees, except those with $P$. serotina stocks, showed curl symptoms. The one Bartlett on Bartlett seedling that was free of curl was very weak and apparently severely affected by slow decline. In contrast, the trees with curl made as much growth during 1965 as the exposed controls (table 1). Only one of the nine Bartletts on P. calleryana, previously psyllainfested, was free of curl, but it was vigorous and made as much shoot growth as the average for the treatment. One of the four Bartletts on Old Home was free of curl, and it was as vigorous as the three with curl. With Bartletts on $P$. serotina, 11 of the 19 did not show curl, and 10 of these 11 were weak. Three of the remaining eight trees with curl made less than average growth for the treatment.

Both of the Bartlett trees with Bartlett seedling rootstocks that were caged during 1962 and 1963 showed curl in October, 1965 (table 5). Two of the three previously caged Bartletts on Old Home stocks were free of curl, however; they were vigorous and made about the same amount of shoot growth as the one with curl. This suggested that the cages gave some protection against curl, possibly by delaying its transmission by psylla feeding until the cages were removed. Where more trees were used, however, as in the case of Bartlett on $P$. serotina, four of the 12 surviving trees were free of curl. These made approximately half as much average growth as those with curl. The Bartlett tree with $P$. ussuriensis rootstocks that showed no curl made less than a third as much shoot growth as the one with curl. With the exception of the two trees with Old Home stocks, therefore, the trees that remained free of curl symptoms evidently lacked the vigor to show the symptoms. 
Evidently, the influence of the diferent treatments and types of rootstocks on the amount of visual curl symptoms was limited mainly to their effect on vigor, with the trees making the most growth showing the highest incidence of curl.

Assuming that curl is caused by a virus, the question is: How and when did the Bartlett trees become infected? Since all of the Bartlett scion wood came from the same tree, the virus could have come from the parent tree, which, unfortunately, was pulled in 1964 to make way for campus expansion and could not be examined for curl symptoms. Another possibility was that pear psylla inoculated the trees with curl virus while they were developing in the experimental plot. Since the cages apparently gave some protection against curl, an insect, presumably the pear psylla, must have played an important role in transmitting the disease. No observations of curl were made in the plot until October, 1963, and then only trees were severely curled leaves were noted. Figure 16 shows an ownrooted Old Home tree with severe curl symptoms-proving that the disease was in the University orchard in 1961. Still another possible source of the curl was from the seedling rootstocks or the own-rooted Old Home rootstocks. The uniformly high percentages of curl on vigorous trees with any of the stocks as well as the protection against curl by caging, however, tend to diminish the role of rootstocks as a primary source of curl. Most likely a combination of several factors was required for the high incidence of curl symptoms.

\section{Winter Nelis trees}

Incidence of curl among the Winter Nelis trees was similar to that noted above for Bartlett. Exposed-control trees with Old Home or Bartlett, Winter Nelis or P.calleryana seedling stocks had high percentages of curl, while those with $P$. serotina and $P$. ussuriensis stocks had significantly lower percentages of curl (table 6). A comparison of the mean shoot growth made by these trees (table 2) reveals that the most vigorous scion-stock combinations showed the most curl.

Five of the 35 exposed-control Winter Nelis trees with Bartlett seedling stocks were free of curl symptoms (table 6), and four of the five made less growth in 1965 than the average for the treatment (table 2). For the 30 trees with curl, only four made less than average growth. Five of the 45 trees with Winter Nelis seedling rootstocks were free of curl, but only one was low in vigor. Five of the remaining 40 with curl made less than average growth. Six of the 36 trees with $P$. calleryana stocks were free of curl, and only two were low in vigor. Three of the remaining 30 with curl made poor growth. All of the trees with Old Home stocks showed curl, and all made vigorous growth. Ten of the 14 trees with $P$. serotina stocks were free of curl. Five of these made as much growth as the average for the treatment, and five made very little growth. The four trees with curl made as much or more growth than the average for the treatment. Seven of the 13 trees with $P$. ussuriensis stocks showed no curl, and all seven made less than the average growth for the treatment. Only one of the six trees with curl made less than average growth.

The relationship between curl and red foliage was inconsistent for the Winter Nelis trees under exposed control, as it was for the Bartlett variety.

For the trees previously subjected to psylla infestation, all seven of the Winter Nelis with Bartlett seedling stocks showed curl in October, 1965, and all were vigorous (tables 2 and 6 ). Eight of the 10 trees with $P$. calleryana stocks had curl and all made vigorous growth. The four Winter Nelis on Old Home 
showed curl. Three were vigorous, but one produced only about half as much shoot growth in 1965 as the average for the treatment. Sixteen of the surviving 22 trees with $P$. serotina stocks were free of curl. Ten of these made less than average growth for the treatment. For the six trees with curl, only one made less than average growth. The three psylla-infested trees with $P$. ussuriensis stocks had curl, and all made vigorous growth.

The three Winter Nelis trees with Bartlett seedling stocks that were caged during 1962 and 1963 made vigorous growth during 1965 and showed curl symptoms (tables 2 and 6). Caged-control trees with Old Home stocks were exceptional, since the two showing no curl made more than average growth, while the two with curl made less than average growth. Two of the eight cagedcontrol trees with $P$. serotina stocks were free of curl. One of these made no shoot growth in 1965, but the other made average growth for the treatment. Only one of the six with curl made less than average growth. All four of the Winter Nelis trees with $P$. ussuriensis stocks made good growth in 1965, but two showed curl and two were free of curl.

Thus, protecting the Winter Nelis trees from psylla visitation during 1962 and 1963 did not prevent most of them from contracting curl, presumably after the cages were removed. It appears, however, that the cages delayed or prevented some of the trees from becoming infected, since their freedom from curl symptoms could not be explained on the basis of lack of shoot growth.

Although the majority of the vigorous Winter Nelis trees under the different treatments showed curl symptoms, the relationship between vigor and curl was less consistent than for the Bartlett trees. The differences in the percentages of vigorous trees show- ing no curl symptoms between the two varieties could be due to the fact that the Bartlett scion wood came from one tree, while the Winter Nelis wood came from a number of trees. The high percentages of trees with curl and the random distribution of trees that were free of curl, however, do not indicate variations in scion wood. It seems more likely that nearly all of the scion wood carried curl or that psylla transmitted curl to the developing scions within the experimental plot. The incidence of curl for the trees with Old Home stocks suggests that the latter possibility is nearer the truth. All of the exposedcontrol trees of both Bartlett and Winter Nelis with Old Home stocks showed curl symptoms, but following caging, two of three Bartletts on Old Home and two of four Winter Nelis on Old Home were free of curl. The cages evidently prevented or delayed curl transmission by psylla.

\section{Hardy trees}

Most of the Hardy trees with Bartlett, Winter Nelis, or $P$. calleryana seedling rootstock showed curl symptoms, while those with $P$. serotina stocks showed significantly less curl (table 7). A comparison of the shoot growth made by these trees (table 3) again showed that the trees with the most curl also made the most growth. Since there were no significant differences in the amount of red foliage, it appears that psylla feeding (or psylla feeding and pear decline virus) was the predominant factor influencing the foliage color of the trees with $P$. serotina stocks, while curl may have accounted for a portion of it in the others. (The relationship between curl and red foliage for the Bartlett trees was discussed previously.)

All 21 of the exposed control Hardy trees with Bartlett seedling rootstocks showed curl symptoms (table 7). The detailed data showed that only one of 


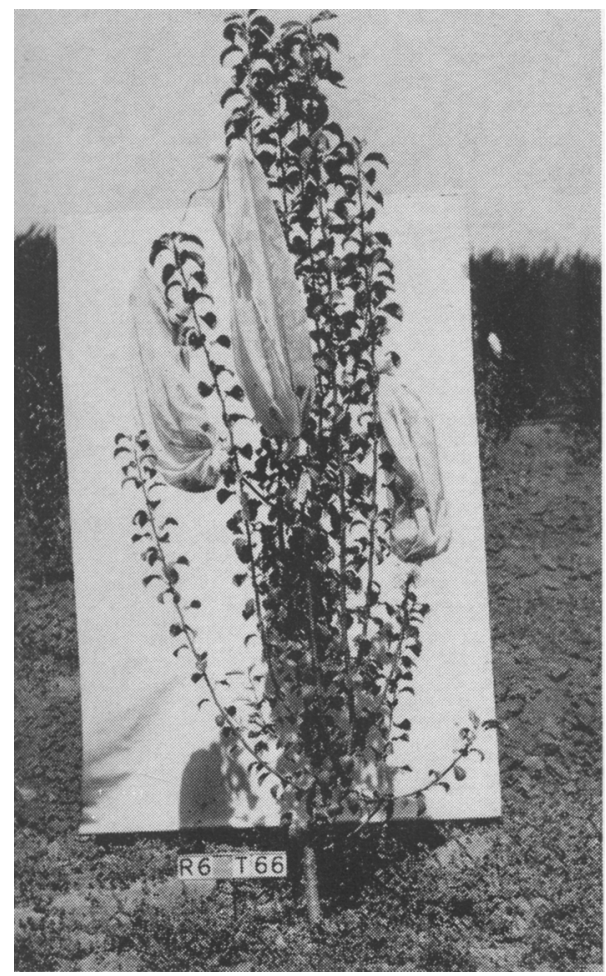

Fig. 1. Own-rooted Old Home tree after six weeks of heavy psylla infestation on three branches by means of organdy sleeve cages. August 30, 1962.

Fig. 2. Below: Experimental plot during the summer of 1962 .

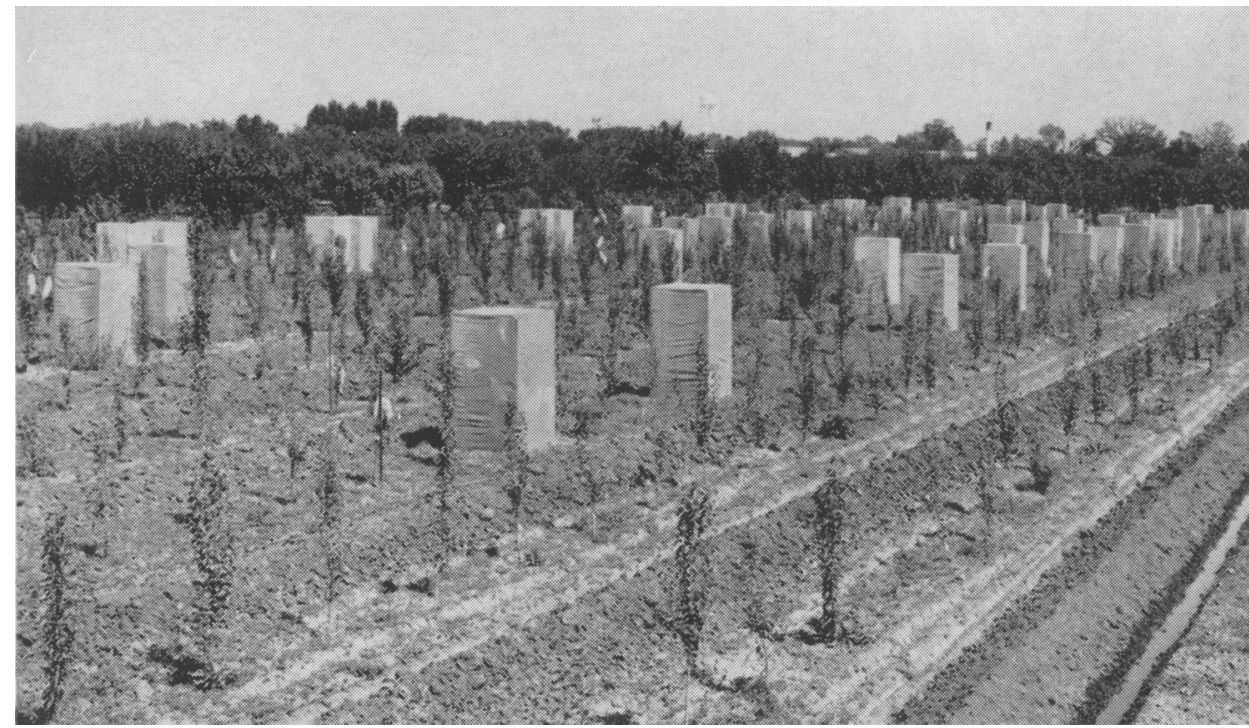




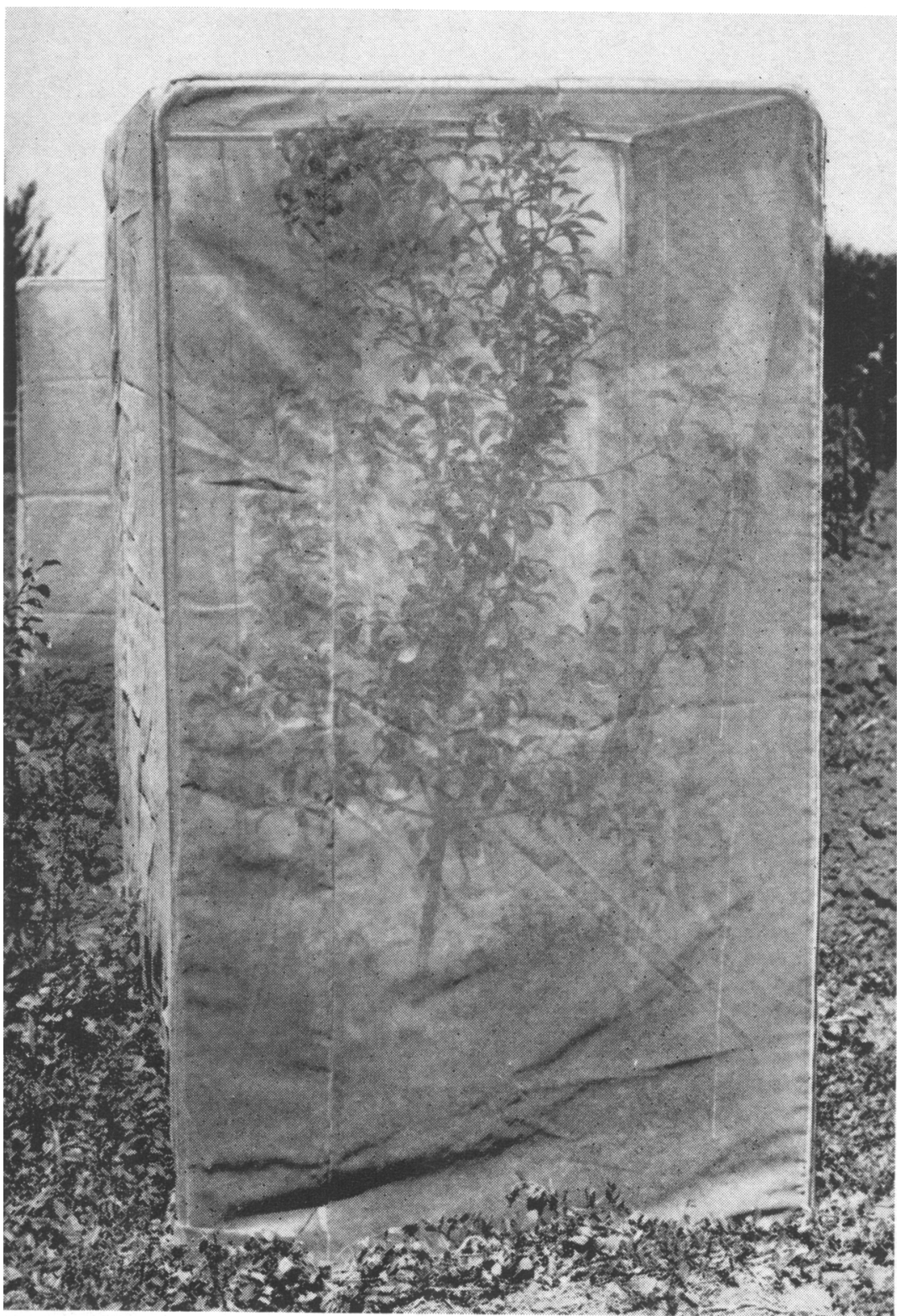

Fig. 3. Saran cloth cages used to control psylla visitation on the experimental trees. August 30, 1962. 


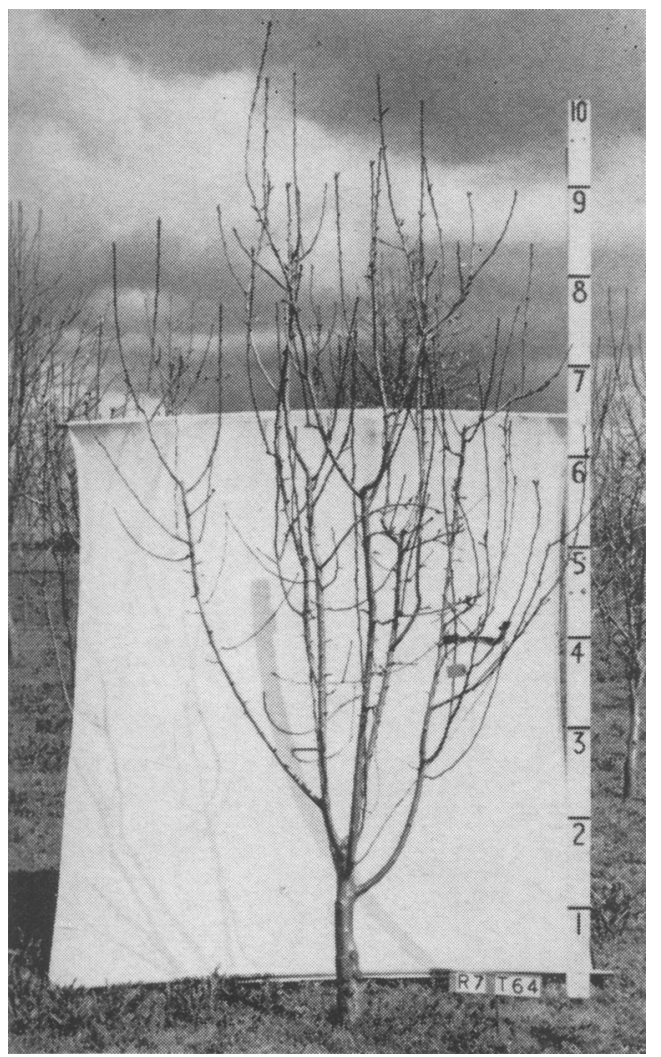

NOTE: The measuring board used to indicate the height of the trees was marked in feet. A meter stick (39.37 inches) was photographed with the root systems to indicate their relative sizes.

Fig. 4. Bartlett tree with a Bartlett seedling rootstock, five years after planting, and its root system. Trunk circumference was $26.8 \mathrm{~cm}$ compared with an average of $18.8 \mathrm{~cm}$ for all surviving exposedcontrol trees of this combination.

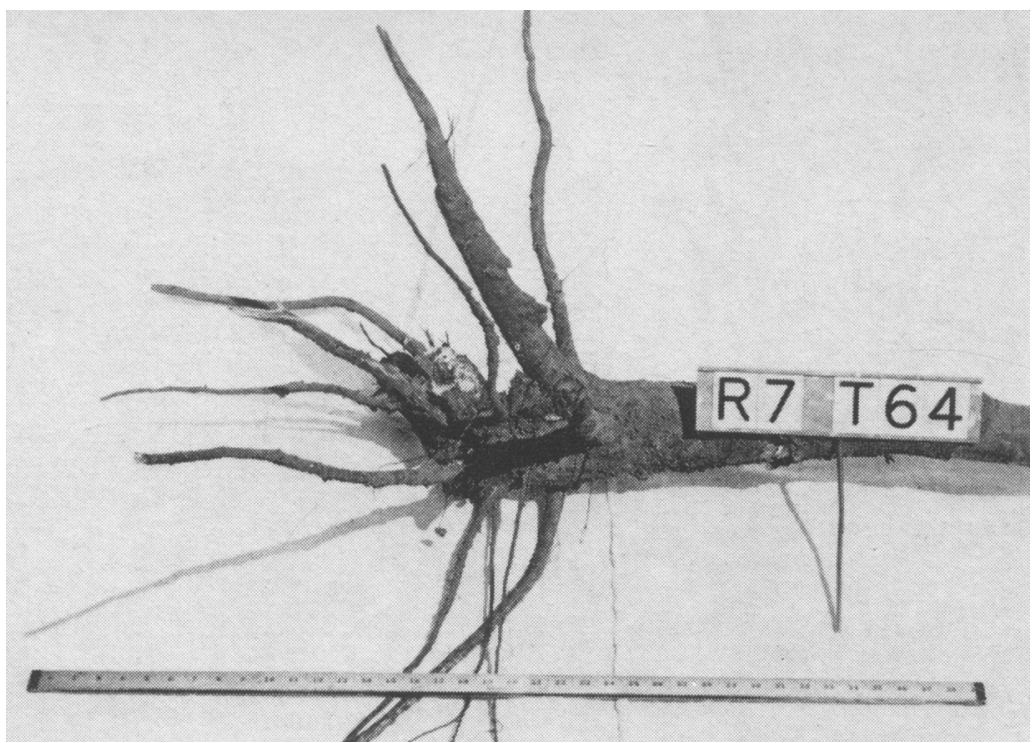


Fig. 5. Bartlett tree with a Winter Nelis seedling rootstock, five years after planting, and its root system. Trunk circumference was $26.5 \mathrm{~cm}$ compared with an average of $20.8 \mathrm{~cm}$ for all surviving exposed-control trees of this combination.
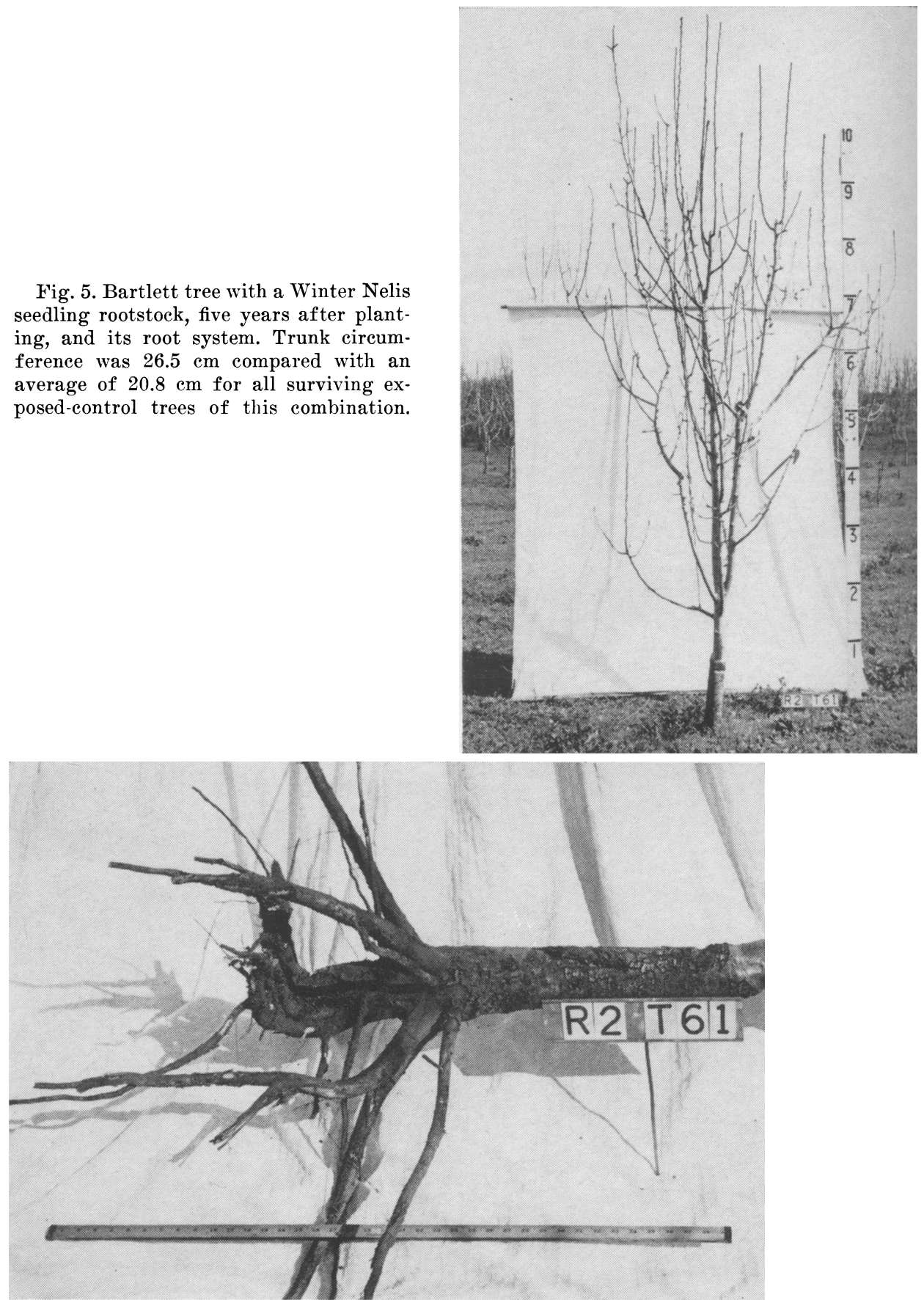


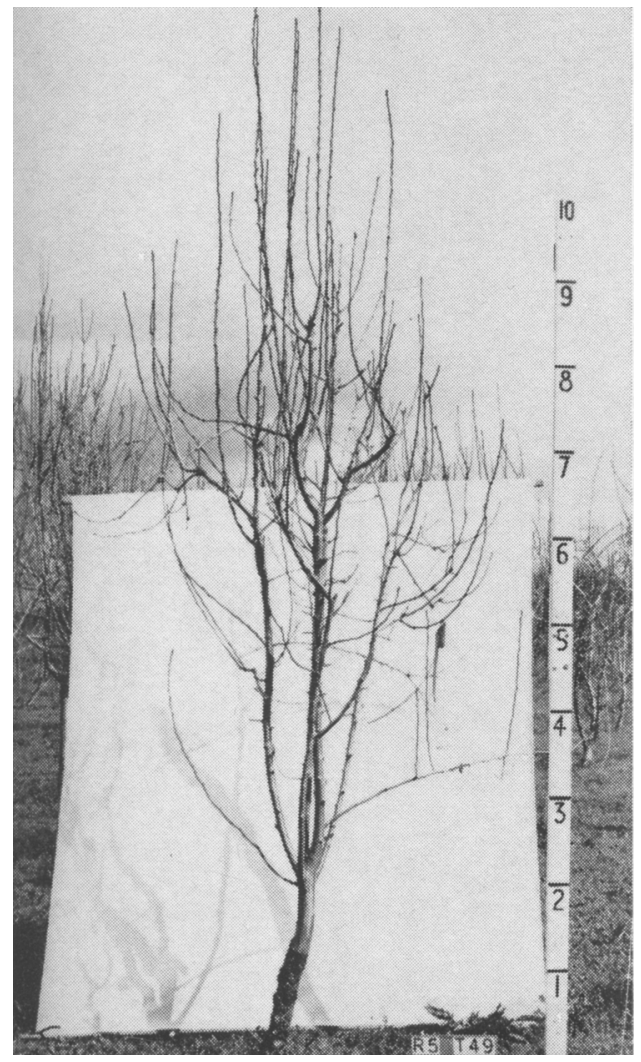

Fig. 6. Bartlett tree with a Pyrus calleryana seedling rootstock, five years after planting, and its root system. Trunk circumference was $25.0 \mathrm{~cm}$ compared with an average of $20.8 \mathrm{~cm}$ for all surviving exposed-control trees of this combination.

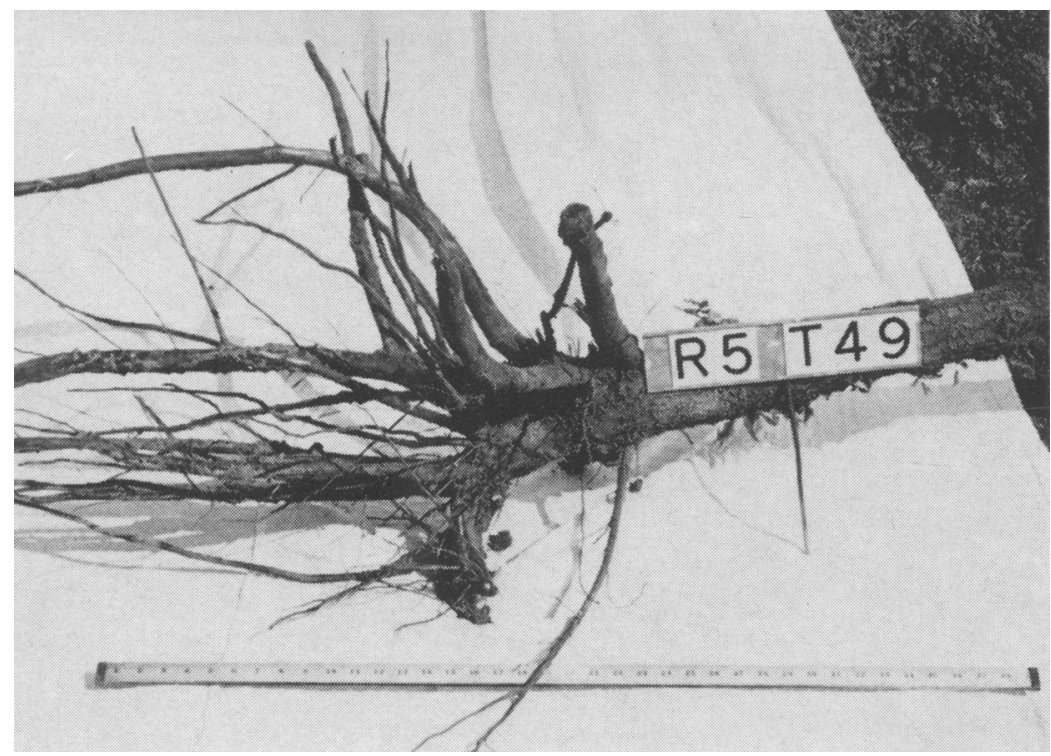


Fig. 7. Bartlett tree with own-rooted old Home rootstock, five years after planting, and its root system. Trunk circumference was $26.3 \mathrm{~cm}$ compared with an average of $22.1 \mathrm{~cm}$ for all surviving exposedcontrol trees of this combination.
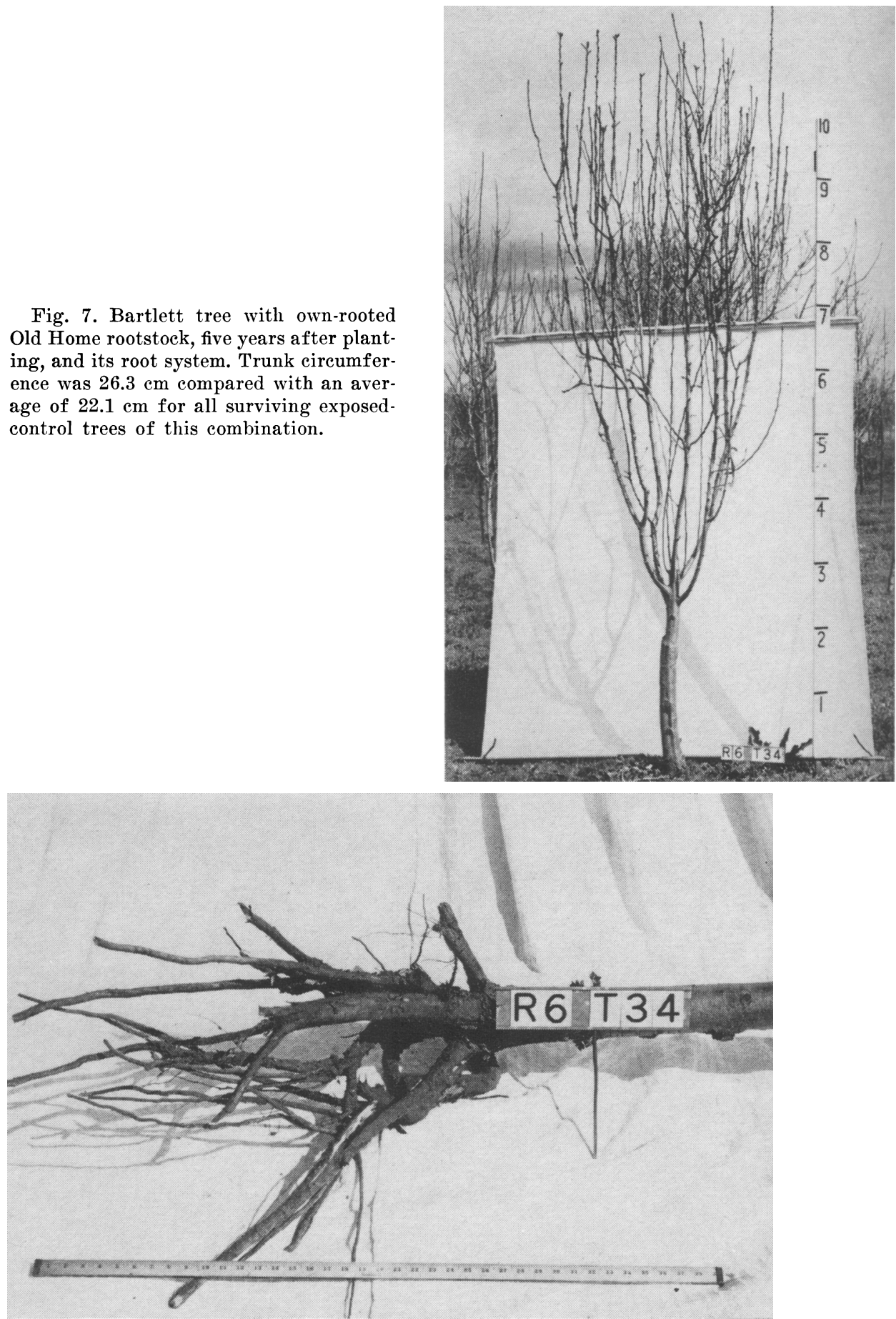


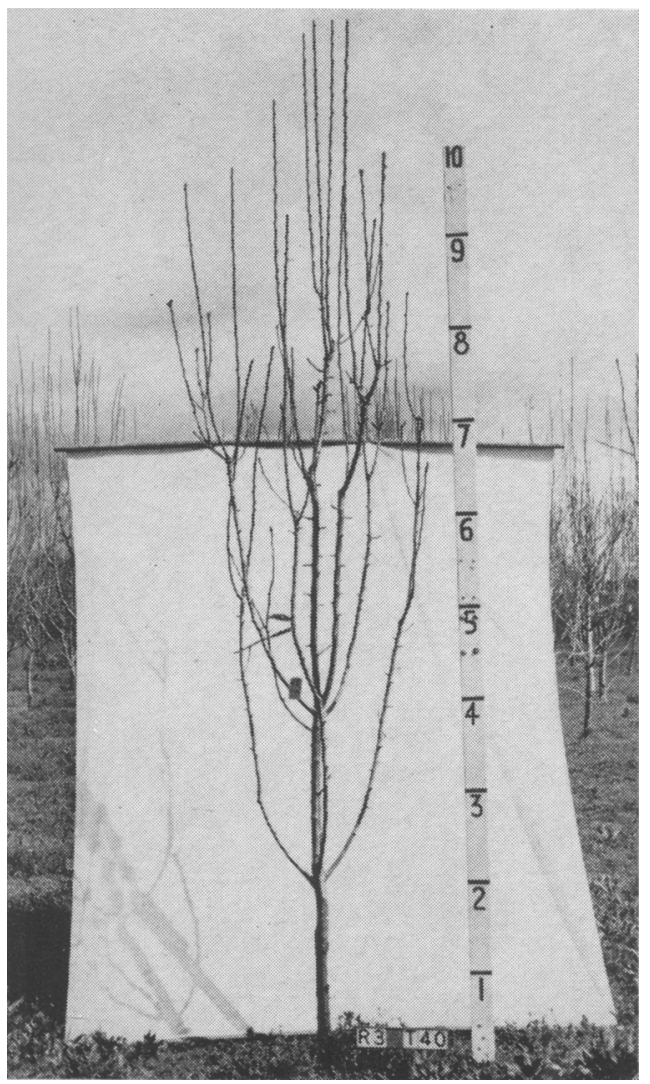

Fig. 8. Bartlett tree with a Pyrus serotina seedling rootstock, five years after planting, and its root system. Trunk circumference was $14.5 \mathrm{~cm}$ compared with an average of $12.2 \mathrm{~cm}$ for all surviving exposed-control trees of this combination.

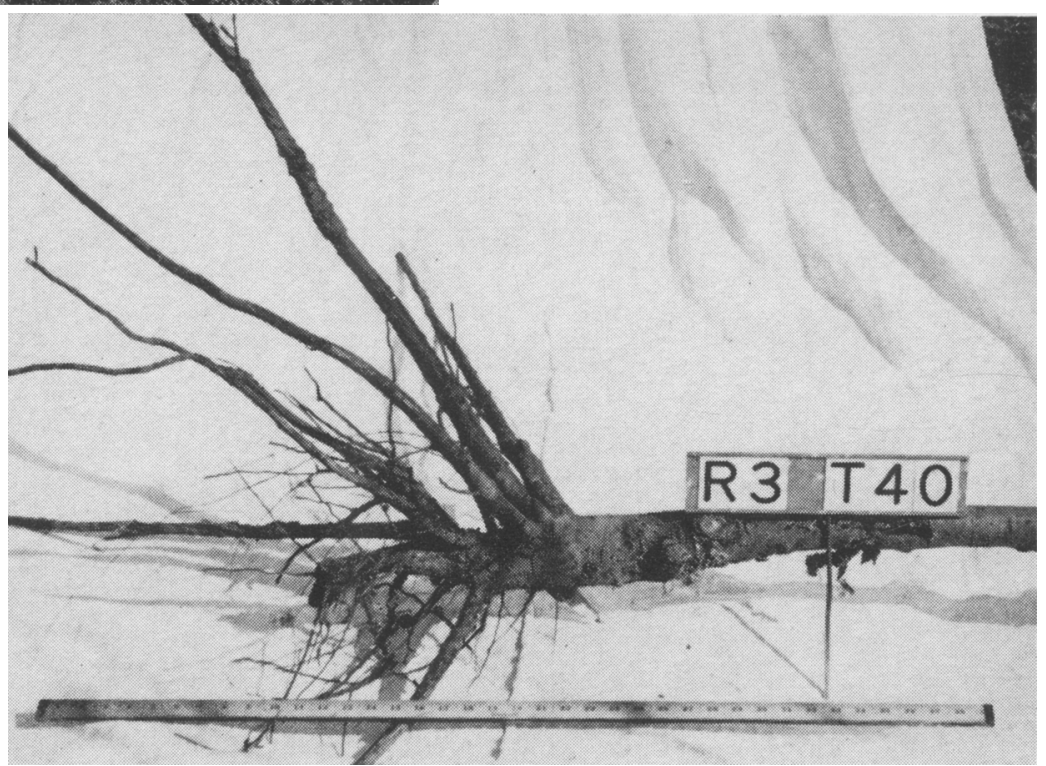


Fig. 9. Bartlett tree with a Pyrus ussuriensis seedling rootstock, five years after planting, and its root system. Trunk circumference was $23.7 \mathrm{~cm}$ compared with an average of $13.8 \mathrm{~cm}$ for all surviving exposed-control trees of this combination.
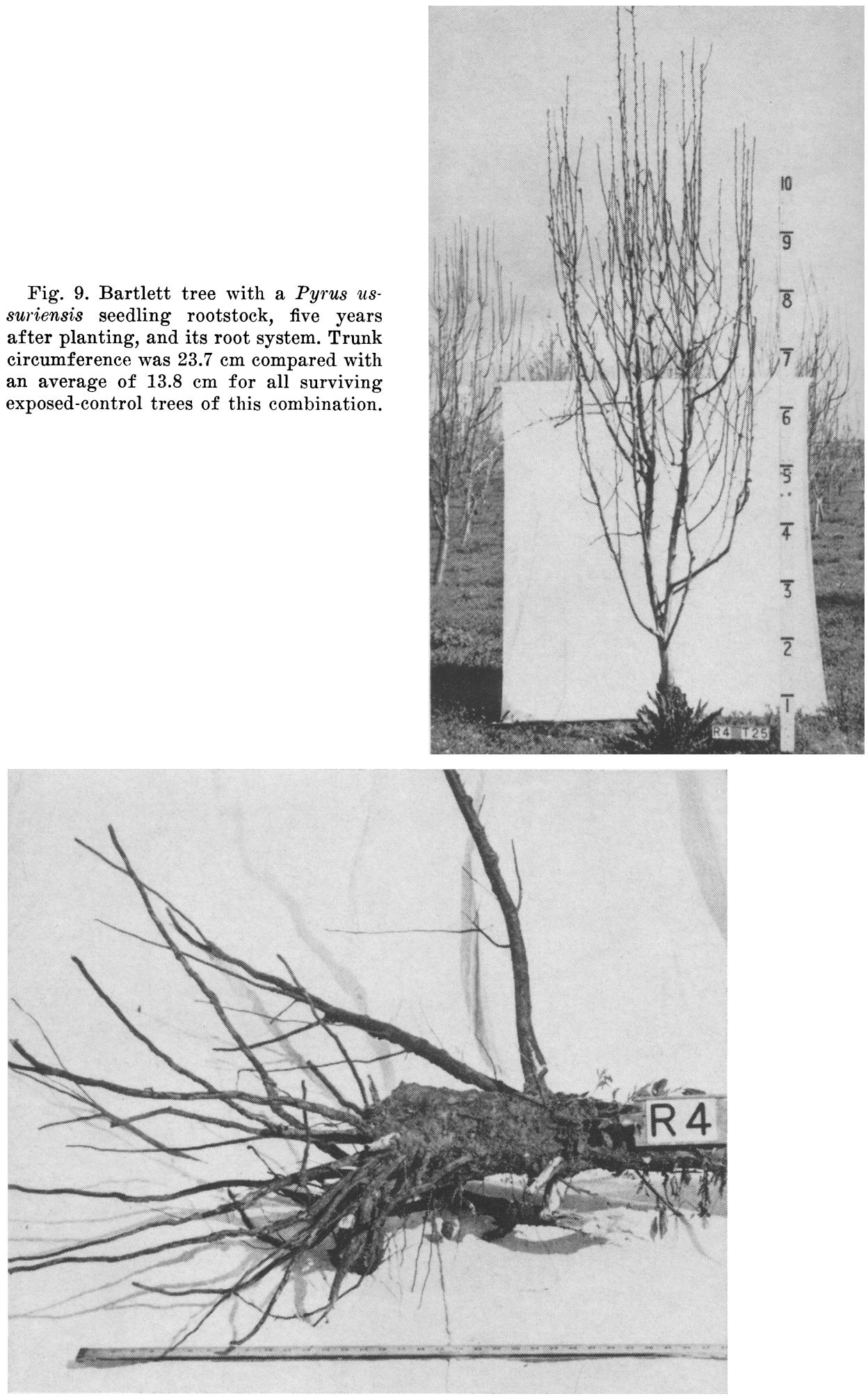


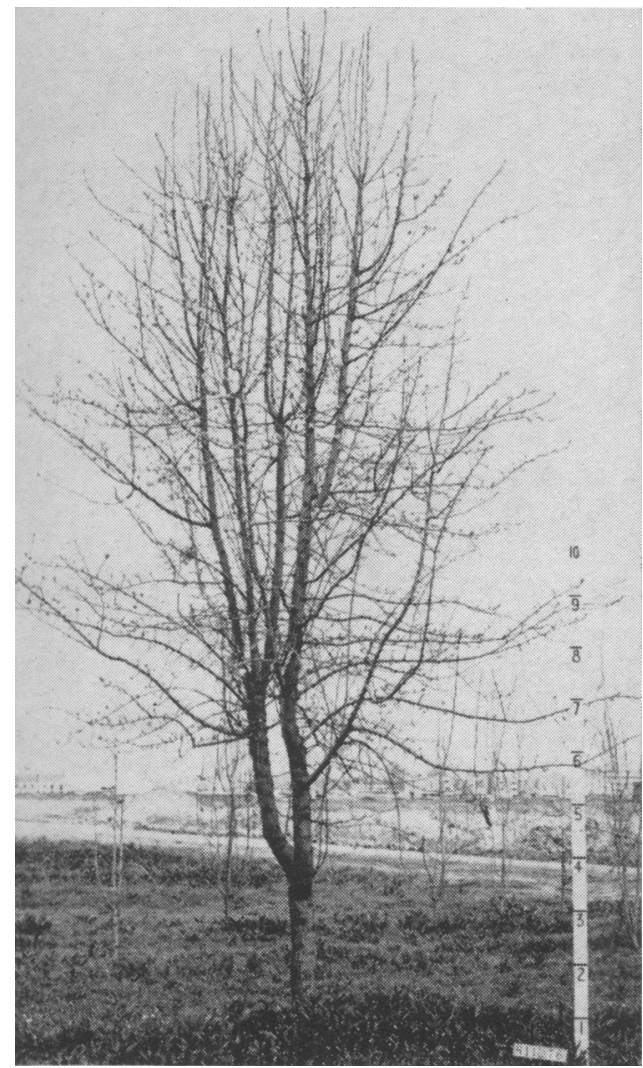

Fig. 10. Pyrus calleryana seedling tree, five years after planting, and its root system. Trunk circumference was $55.7 \mathrm{~cm}$ compared with an average of $44.0 \mathrm{~cm}$ for all surviving exposed-control $P$ calleryana trees.

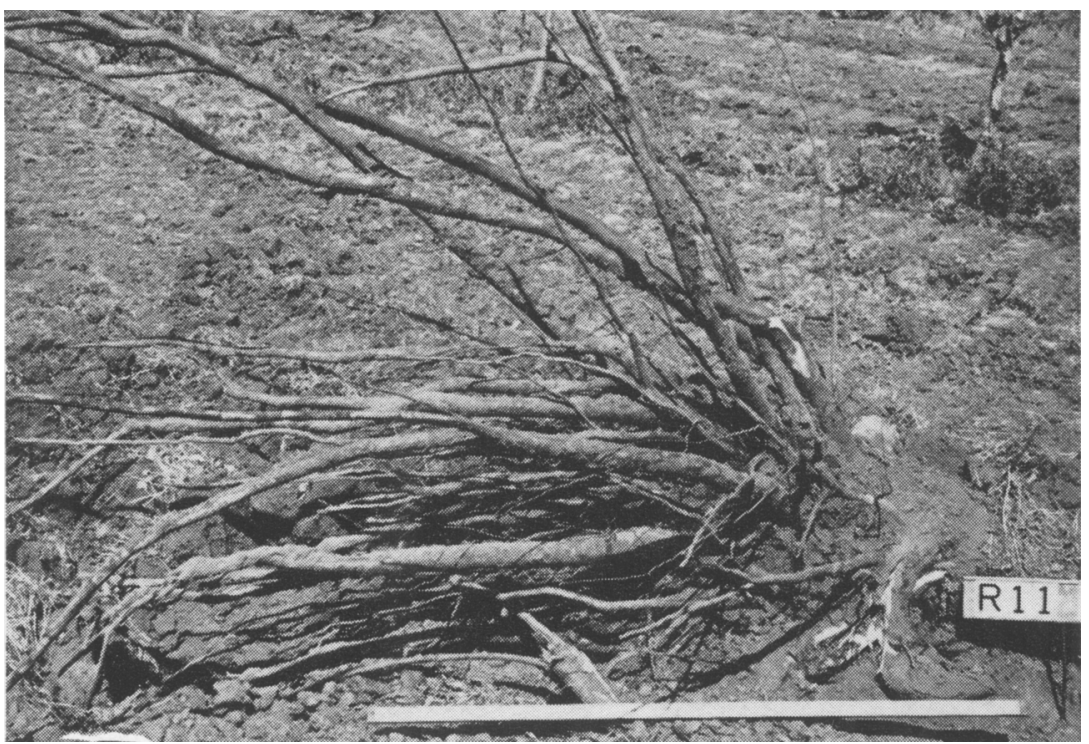


Fig. 11. Own-rooted Old Home tree, propagated from hardwood cuttings, five years after planting, and its root system. Trunk circumference was $35.7 \mathrm{~cm}$ compared with an average of $32.3 \mathrm{~cm}$ for all surviving exposed-control Old Home trees.
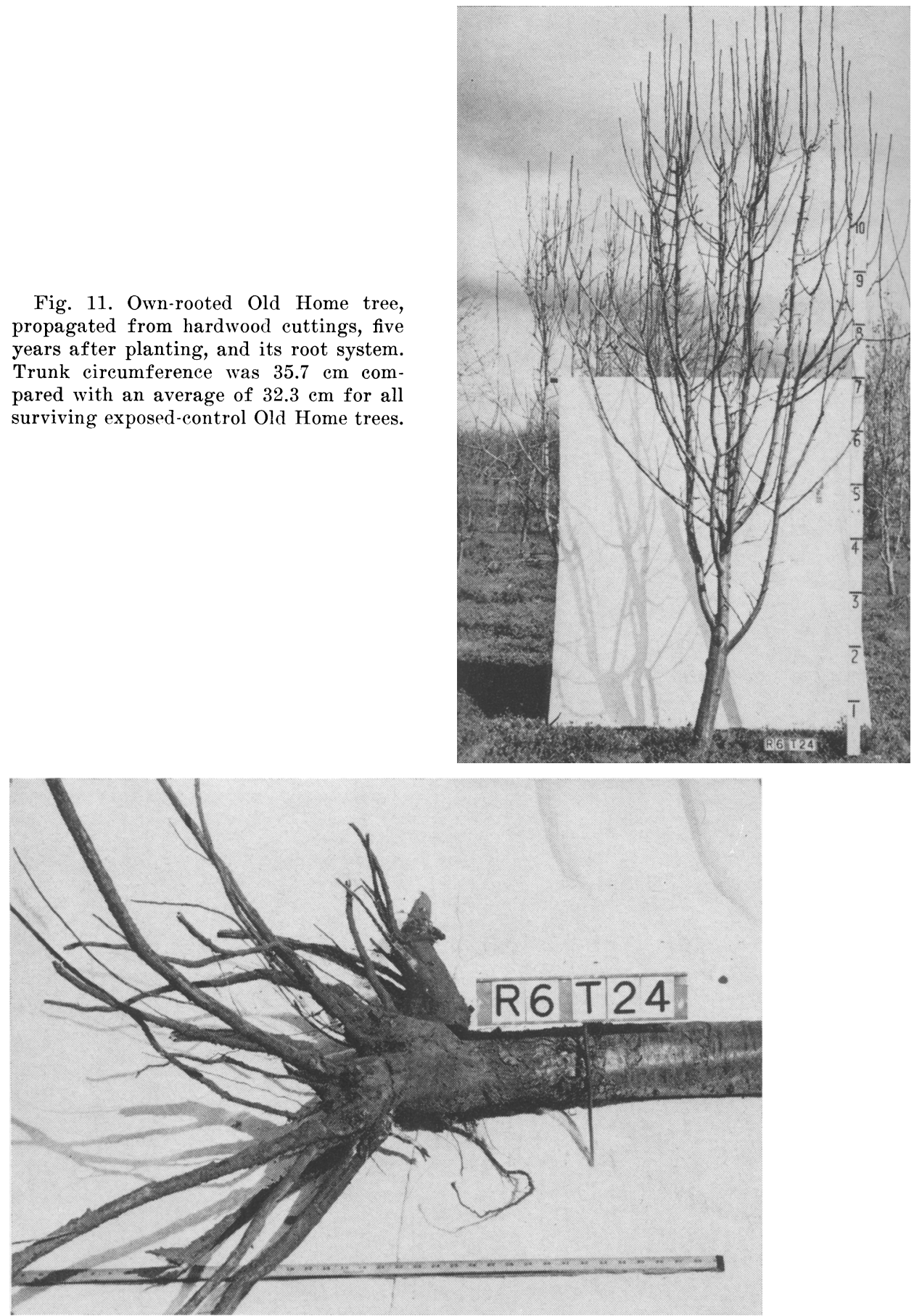


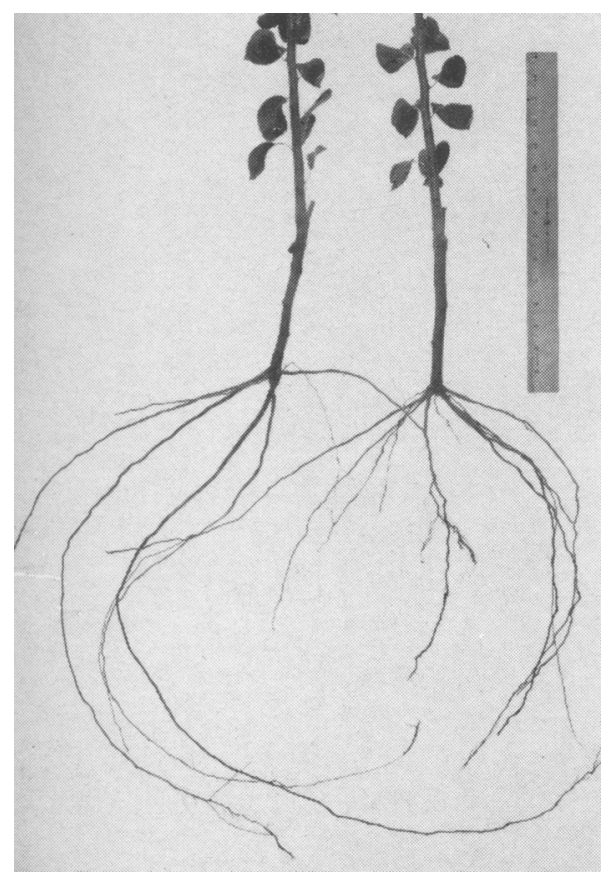

Fig. 12. Old Home nursery trees propagated from hardwood cuttings, shown with 1-foot rule. Note that the roots developed from one plane at the base of the cuttings. August 15, 1961.

Fig. 13. Below: roots of own-rooted old Home tree, propagated from hardwood cuttings, five years after planting. Note roots that developed above original ring of roots.

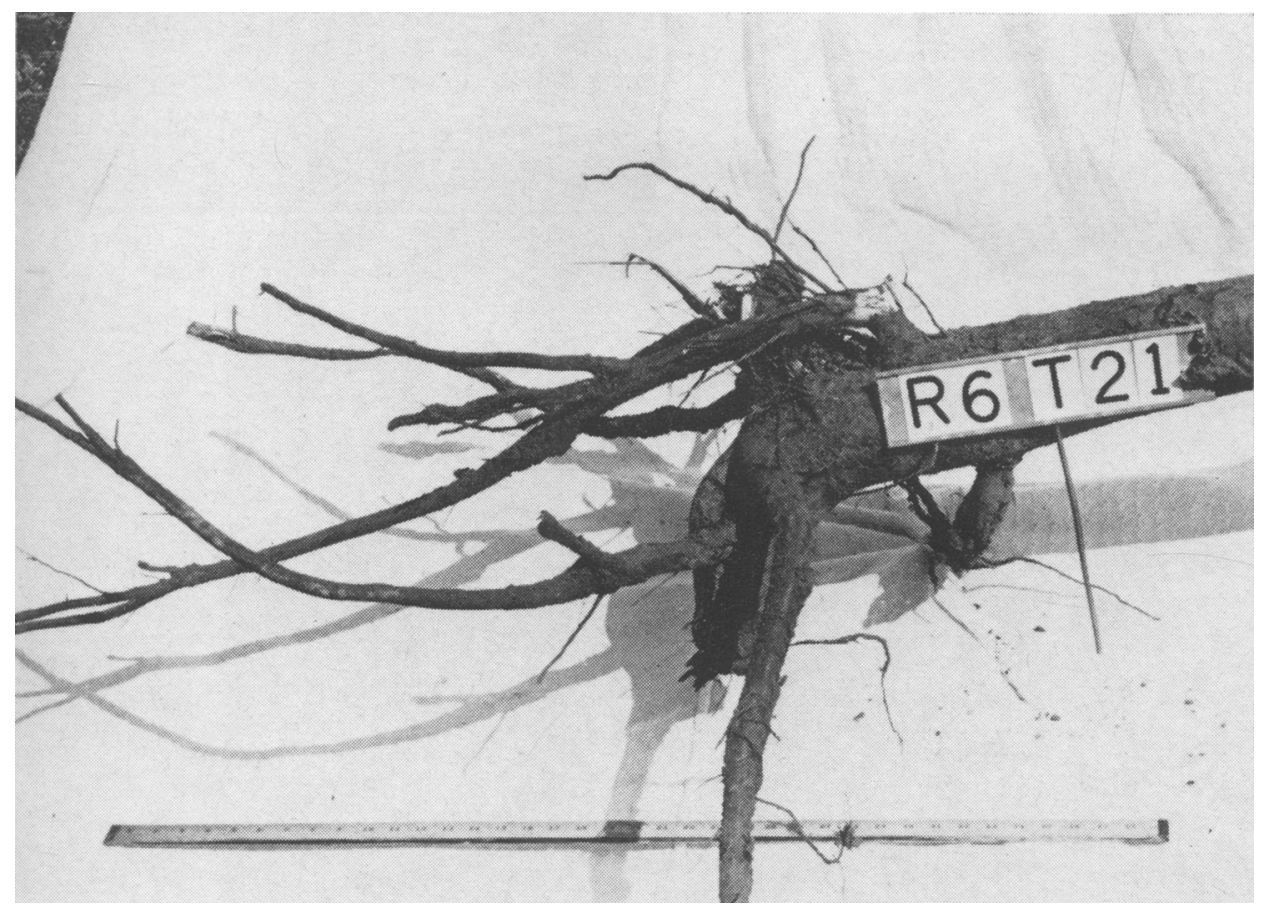


Fig. 14. Pyrus serotina seedling tree, five years after planting, and its root system. Trunk circumference was $20.0 \mathrm{~cm}$ compared with an average of $20.5 \mathrm{~cm}$ for all surviving exposed-control $P$. serotina trees.
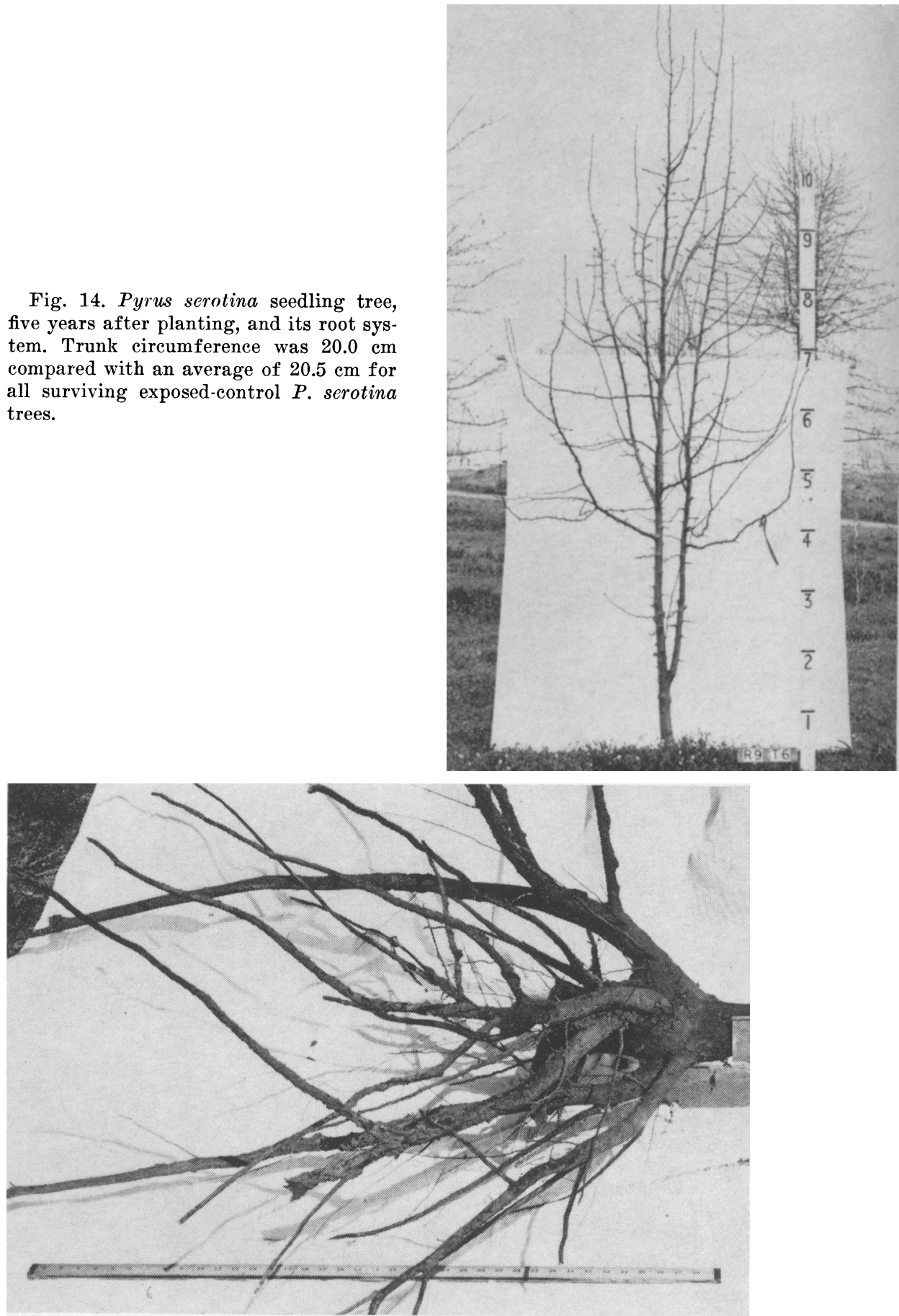


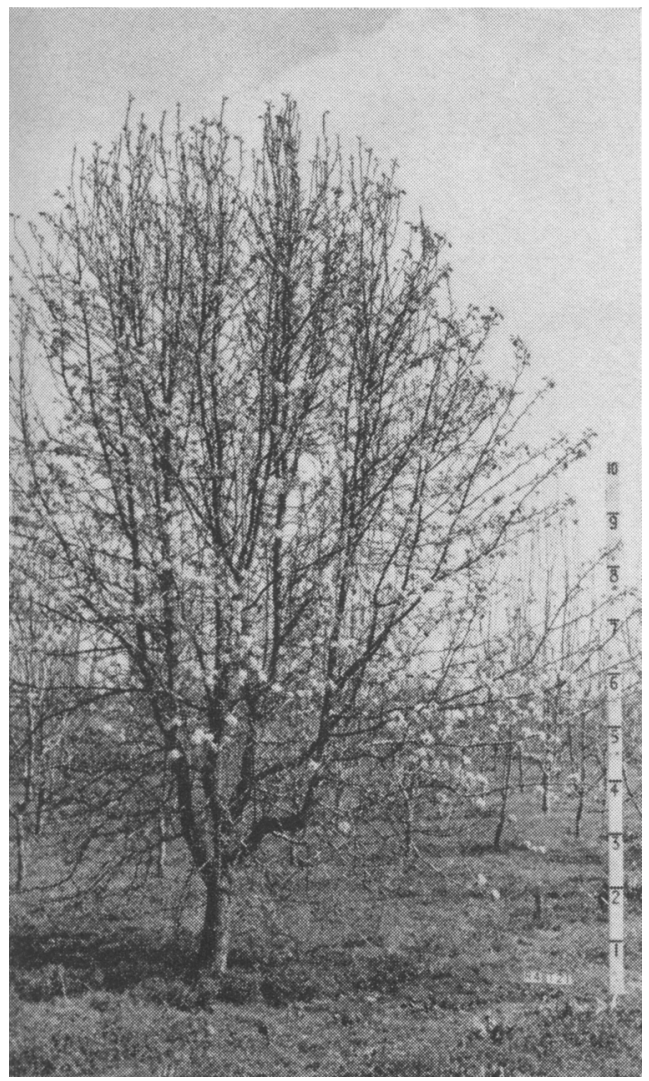

Fig. 15. Pyrus ussuriensis seedling tree, five years after planting, and its root system. Trunk circumference of this exceptionally large specimen was $51.7 \mathrm{~cm}$ compared with an average of $24.5 \mathrm{~cm}$ for all surviving exposed-control $P$. ussuriensis trees.

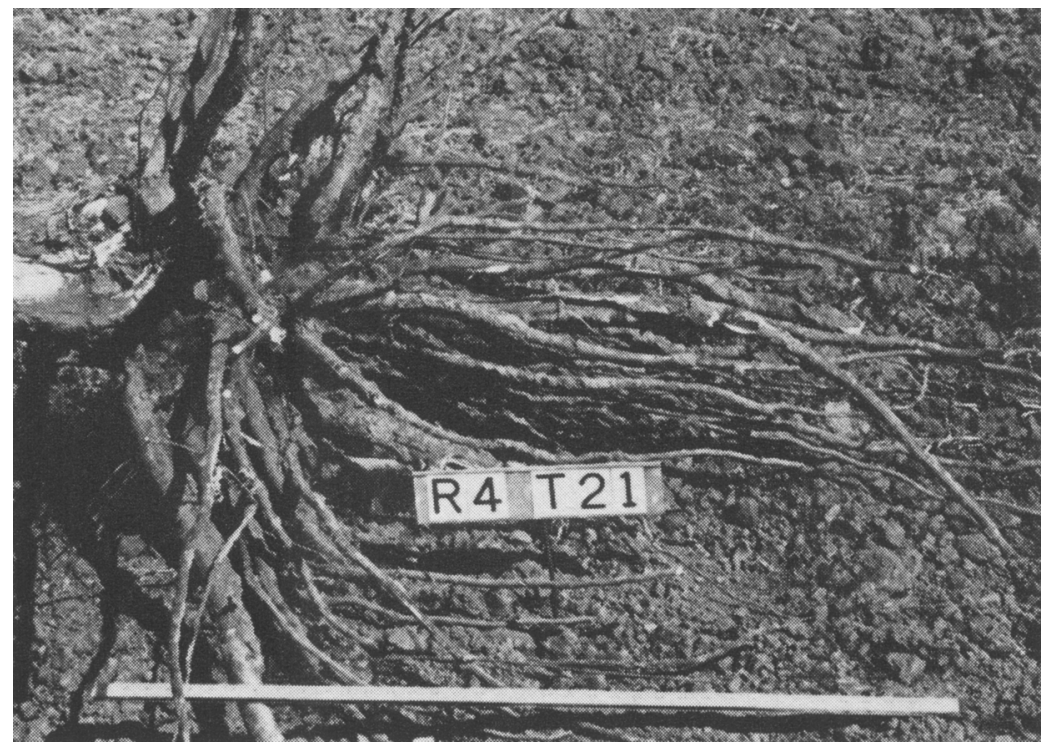




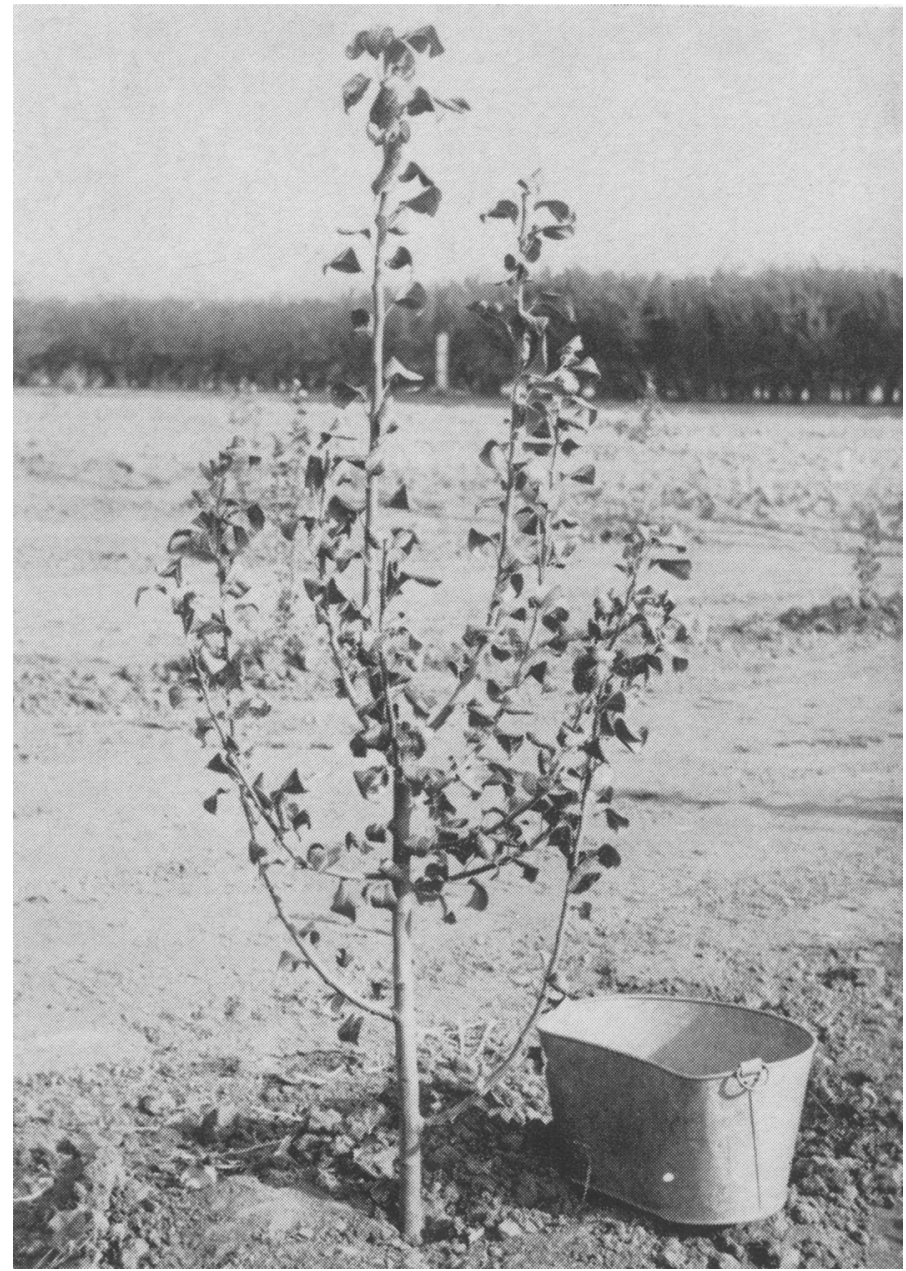

Fig. 16. Own-rooted Old Home tree with severe symptoms of leaf curl after one growing season. November 2, 1961. (H. T. Hartmann) 


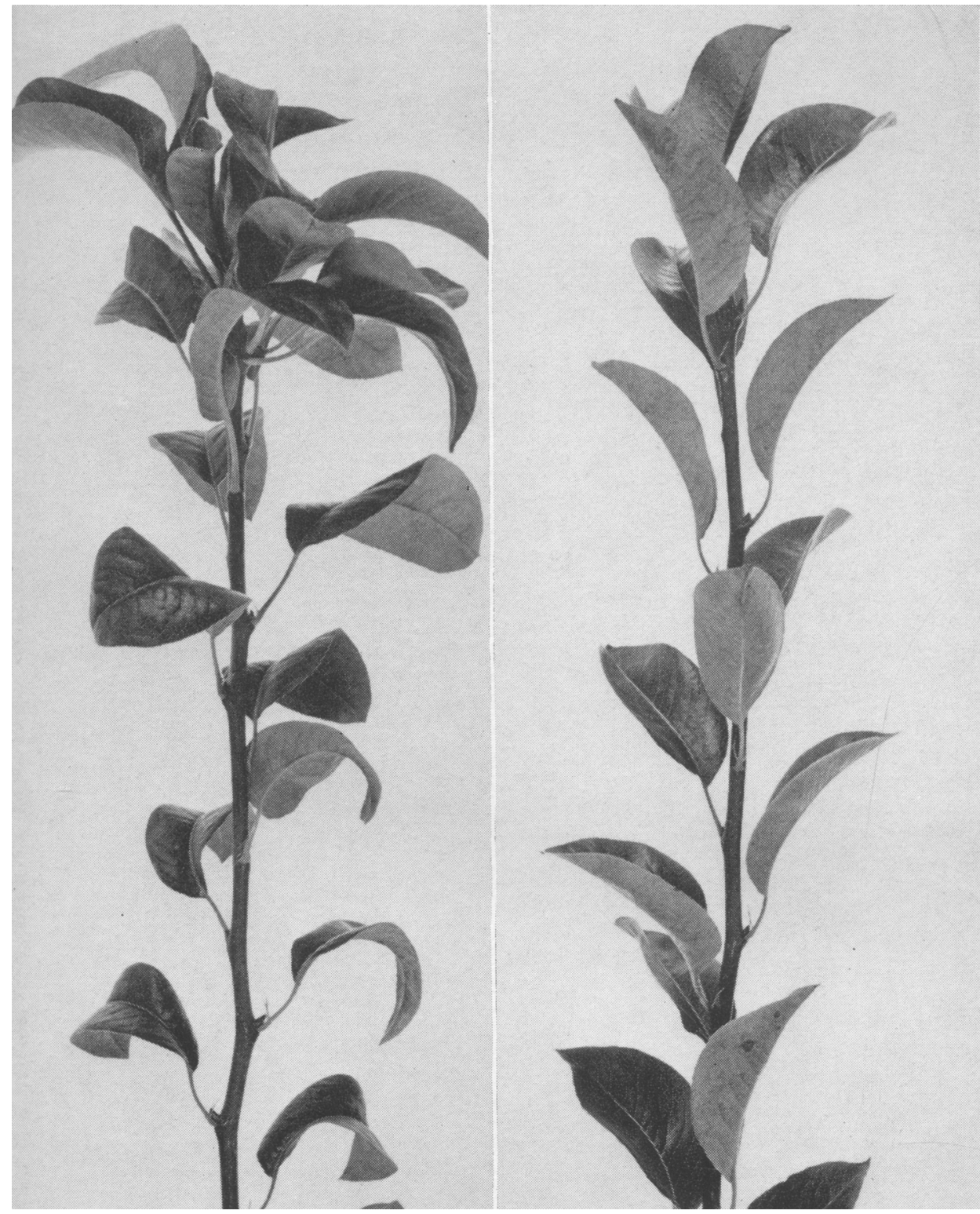

Fig. 17. Bartlett shoot with curl symptoms (left) and without curl symptoms (right). 


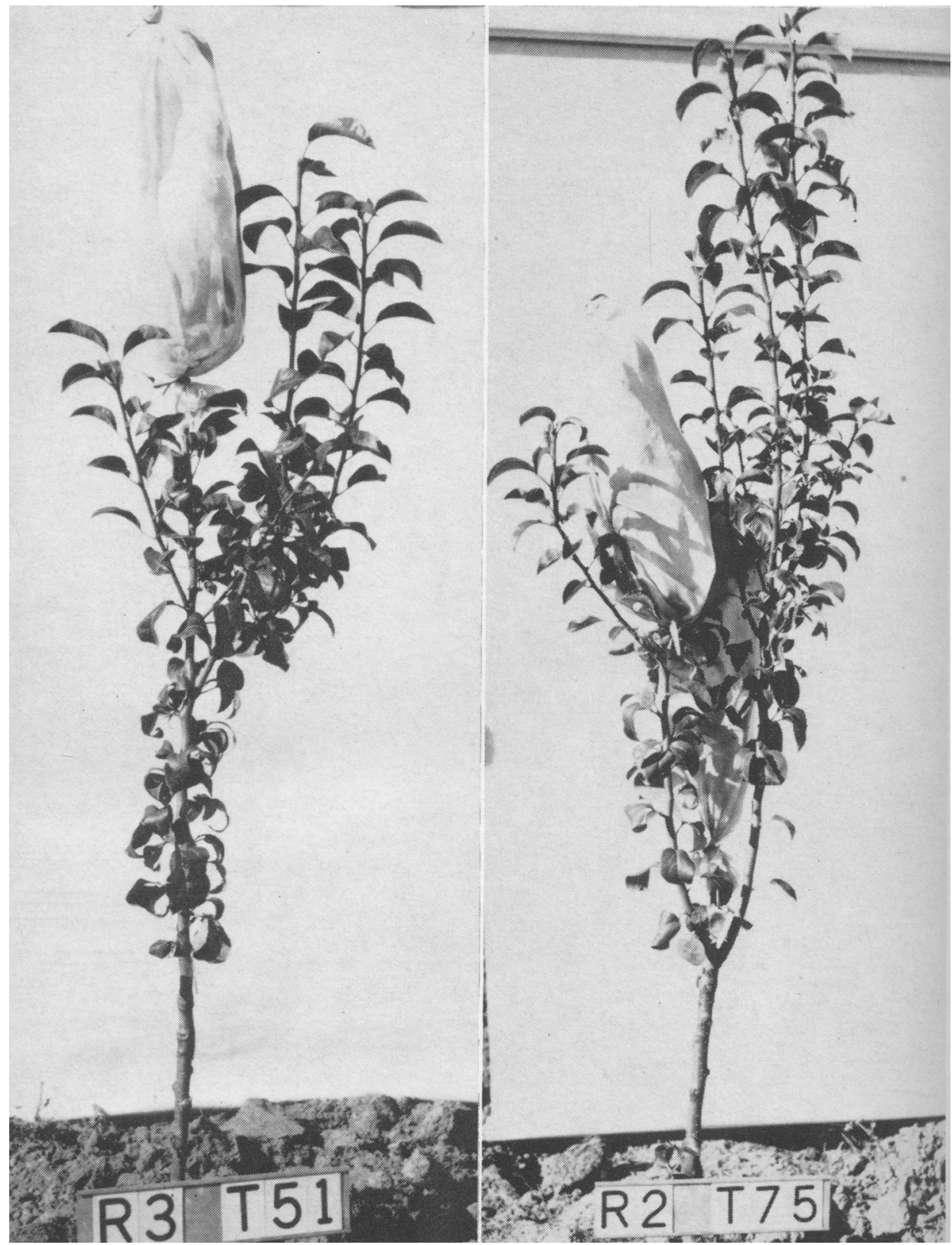

Fig. 18. Bartlett trees with Pyrus serotina rootstocks after one and two branches were exposed to high populations of psylla, apparently free of decline virus, for three months. Note leaf curl symptoms below the bags. October 30, 1963. 


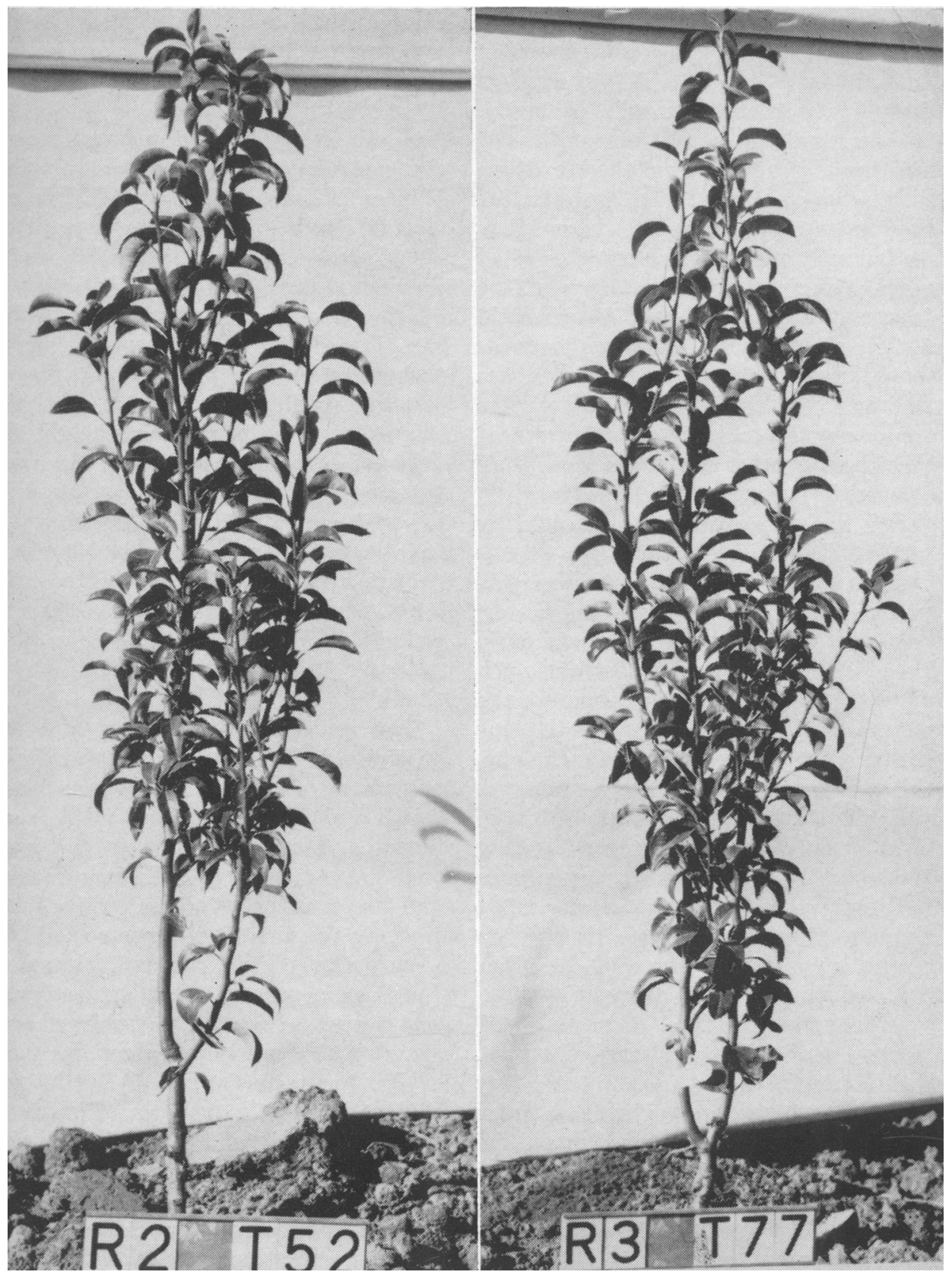

Fig. 19. Bartlett trees with Pyrus serotina rootstocks used as controls for trees shown in fig. 18. Note that they are free of curl symptoms. October, 1963. 
these made poor growth. Two of the 23 trees with Winter Nelis stocks were free of curl; they made about average growth for the treatment (table 3 ). All except three of the trees with curl made good growth. All of the Hardy on $P$. calleryana showed curl. Only two of these were relatively low in vigor; they made about half as much growth as the average for the treatment. Six of the 17 surviving Hardy on $P$. serotina did not show curl. Of these, one made as much growth as the average for the treatment, while the remaining five made very little growth. Only two of the 11 trees with curl made less than average growth.

For the trees previously infested by psylla, all five of the Hardys on $P$. calleryana showed curl, and all were vigorous. Three of the four surviving Hardy trees with $P$. serotina stocks showed curl. Each of these made as much growth or more than the average for the treatment during 1965, while the one with no curl made approximately onethird as much growth.

Both of the Hardy trees with $P$. serotina stocks that were caged during 1962 and 1963 showed curl symptoms in October, 1965. One of these made about as much growth as the average of the exposed controls, and the other made about one-third as much.

In summary, 71 of a total of 80 Hardy trees with curl were vigorous, while only three of the nine trees that were free of curl were vigorous. Since all of the Hardy scion wood came from one tree, the parent tree is a logical suspect as a source of curl. This cannot be verified, however, because the parent tree was pulled in 1964 . On the other hand, it seems equally logical to conclude that the trees were infected with curl while developing in the experimental plot. This reasoning is based on the high percentages of the experimental trees that showed curl symptoms, including those not topgrafted, and the fact that a few of the Hardy trees remained free of the disease.

\section{Non-topgrafted trees}

Significantly higher proportions of the non-topgrafted Bartlett seedling, Winter Nelis seedling, and Old Home trees showed curl than non-topgrafted $P$. calleryana, $P$. serotina, and $P$. ussuriensis seedlings (table 8). A comparison of the trunk circumference measurements made in 1965 (table 4) shows that, with the exception of the $P$. calleryana seedlings, the trees with the largest trunk circumferences had the greatest percentages of curl. The relative amounts of trunk growth made by exposed controls during 1965, however, reveals a poor correlation between growth and curl. Part of the inconsistency probably was due to the general reduction in trunk growth during 1965 - caused in turn by inadequate irrigation.

The relation between curl and red foliage also was inconsistent. With the exception of the $P$. calleryana trees which showed no curl or red foliage, however, the trees showing the least curl ( $P$. serotina and $P$. ussuriensis) had the most red foliage, while those showing the most curl (own-rooted old Home) showed the least red foliage.

The percentage of Bartlett seedlings under exposed control that showed curl symptoms (table 8) was about the same as for trees consisting of Bartlett or Winter Nelis on Bartlett seedling rootstocks (tables 5 and 6 ). This was surprising in view of the genetic variability of pear seedlings and the fact that the seed came from several trees. Only three of the 20 Bartlett seedlings were free of curl symptoms. Two of these made more growth than the average for the treatment during 1965 (table 4), while the third made approximately half the average growth. Only two of the 17 trees with curl made poor growth during 1965. The high inci- 
dence of curl in these seedling trees could indicate that most of the seed carried the virus. It seems more reasonable, however, to conclude that psylla transmitted curl to them while they were in the nursery or after they were planted in the experimental plot.

The percentage of Winter Nelis seedlings with curl symptoms was somewhat lower than for Bartlett, Winter Nelis, or Hardy trees with Winter Nelis seedling rootstocks (tables 5 through 8 ). Six of the 24 Winter Nelis seedlings showed no curl. Three of these made above the average growth in trunk circumference for the treatment during 1965 (table 4 ), while the other three made less than average. All except one of the 18 trees with curl made good growth during 1965.

None of the exposed-control $P$. calleryana seedlings showed curl symptoms or red foliage (table 8), and all showed great vigor (table 4, fig. 10). It is interesting that, when topgrafted to commercial varieties, these seedlings evidently do not impart any resistance to curl to the scion variety (tables 5,6 , and 7 ). $P$. calleryana leaves have wavy margins and other characteristics considerably different from those of $P$. communis. It may be, therefore, that curl expresses itself in $P$. calleryana in some undetected manner or that it is a symptomless carrier of the disease. The fact that the scion varieties showed nearly as high percentages of curl on this stock as they did on Old Home indicates that rootstocks are not primary factors affecting the incidence of curl.

All of the exposed-control own-rooted old Home trees showed curl symptoms, and all were vigorous. The hardwood cuttings from which these trees were developed were taken from a number of Old Home trees in the Pomology orchards at Davis. The senior author and other pomologists in the department remember, however, that leaf curl symptoms have occurred on Old Home trees in the fall for many years. Also, Reimer (1925) presented a photograph (see his fig. 3) of a young Old Home tree topgrafted with Bartlett. The basal leaves on the Old Home portion of the tree show typical curl symptoms. Hence, one might consider the thickening, curling, and reddening of the old Home leaves in the fall as a normal varietal characteristic, except that some Old Home trees are free of curl symptoms, and others show a wide range in the proportion of the leaves showing symptoms. All of the Bartlett and Winter Nelis trees with own-rooted Old Home rootstocks from the same sources and propagation treatment, also showed curl symptoms under exposed control (tables 5 and 6). Therefore, it would be logical to conclude that the curl was transmitted from the Old Home stocks, if it were not for the high percentages of curl in these varieties with the seedling stocks.

Only two of the 12 surviving exposed-control $P$. serotina. seedlings showed curl symptoms in 1965 (table 8 ). Both of these made as much growth as the average for the treatment (table 4). Only two of the 10 trees with no curl symptoms were low in vigor. The remaining seven made about the same amount of trunk growth as the exposedcontrol Bartlett seedlings. Hence, their lack of curl cannot be attributed to lack of vigor. Evidently, the $P$. serotina trees are not as susceptible to curl or they do not develop the symptoms as readily as the $P$. communis trees. Though less vigorous, Bartlett, Winter Nelis, and Hardy trees with $P$. serotina stocks showed a higher incidence of curl (tables 5, 6, and 7) than the non-topgrafted $P$. serotina seedlings.

Pyrus ussuriensis trees also showed a lower incidence of curl (table 8) than Bartlett and Winter Nelis trees with $P$. ussuriensis seedling stocks (tables 5 and 6 ). Only two of the 18 surviving exposed-control $P$. ussuriensis seedlings 
showed curl (table 8), and both of these made approximately the same amount of trunk growth as the average for the treatment (table 4). Only three of the 16 trees showing no curl symptoms were low in vigor. Lack of curl symptoms, therefore, cannot be attributed to poor growth. The low incidence of curl for these trees could be due to cleaner seed, greater resistance, to to psylla preference for $P$. communis leaves. The latter possibility seems unlikely, however, since the three psyllainfested $P$. ussuriensis trees showed no curl symptoms, although they made vigorous growth. It may be that the disease simply does not manifest itself readily in the oriental pear foliage.

All of the Bartlett seedlings and the Old Home trees that were psylla-infested during 1962 and 1963 showed curl symptoms in 1965 (table 8). This does not prove that curl resulted from the psylla infestation, however, because the comparable exposed-control trees also showed high percentages of curl. The three psylla-infested $P$. calleryana trees showed no curl symptoms, although they were very vigorous. Also, no curl was observed on the $P$. serotina and $P$. ussuriensis seedlings. One of the four $P$. serotina seedlings made very little growth during 1965 , but the other three made more growth in trunk circumference than the average for the treatment (table 4). One of the three $P$. ussuriensis trees made poor growth, but the other two were very vigorous. Evidently these trees escaped curl infection in spite of heavy psylla feeding. This is interesting in view of the high incidence of curl found in the commercial varieties with these types of rootstocks.

Caging the trees during 1962 and 1963 did not prevent the Bartlett seedling from showing curl symptoms in 1965 (table 8). One of the five previously caged Old Home trees was free of curl symptoms, however, even though it made vigorous growth during 1965 . Since all of the Old Home trees in both the exposed-control and psylla-infested groups showed curl, it seems that the period of caging gave some protection against the disease.

\section{Supplementary evidence}

As noted previously, Millecan et al. (1963) presented evidence indicating that curl is not related to pear decline, while Kaloostian (personal communication of December 13, 1966) tentatively suggested that curl is caused by a strain of pear decline virus. Jensen et al. (1964) compared the effects in decline-susceptible pear trees of a possible psylla-transmitted decline virus (in virtual absence of psylla toxin) with the effects of prolonged psylla feeding in the absence of virus. The implications regarding leaf curl were not included in the report, but photographs taken during the course of the experiments corroborate evidence of Millecan et al. (1963) that curl is caused by a separate virus.

Jensen et al. (1964) developed psylla presumed to be free of pear decline virus as follows: During March and April, 1963, adult pear psylla were imported from New York, where pear decline had not been reported. Populations of these were developed in the greenhouse on pear seedling foliage not previously fed on by psylla. Stocks of California pear psylla were obtained by dissecting unhatched eggs from the leaves of young greenhouse pear trees on which they were laid and hatching them in petri dishes. The nymphs were then transferred to small pear seedlings in the greenhouse where they matured and reproduced. Psylla, presumably carrying pear decline virus, were developed by caging psylla and allowing them to reproduce on the foliage of trees with pear decline.

During July, 1963, adult psylla from 
the different stocks were caged on young Bartlett pear trees with $P$. serotina rootstocks. One or two organdy cloth sleeve cages, each enclosing 75 to 100 adults, were placed on each tree. Seventy comparable trees were selected at this time for psylla-free controls.

The psylla presumed to be carrying decline virus were caged on 42 trees and allowed to feed for periods of five to eight days, after which the adults and eggs they had laid were destroyed. The short adult feeding periods left no discernible effects on any of the trees until September 11 when some of them started wilting and collapsing with pear decline. By October 30, 1963, 18 of the trees had collapsed, eight showed varying symptoms of pear decline, and 16 remained healthy.

The psylla presumed to be free of pear decline virus were caged on 35 trees and allowed to feed and reproduce for either three or four months. Populations ranging from approximately 500 to several thousand developed on each tree. By October 30, only one of the trees had developed pear decline. The others remained vigorous except for varying amounts of defoliation and stunting of the branches enclosed by the sleeve cages. Photographs of some of these trees, taken October 30, show leaf curl symptoms on leaves directly below the psylla cages (fig. 18). Since all of the control trees remained healthy throughout the season, and comparable photographs of them show no curl (fig. 19), it appears that the curl was transmitted to the test trees by the psylla that were free of pear decline virus. This suggests that the curl and decline viruses are two separate entities. Evidently, the psylla obtained the curl virus inoculum from the young pear seedlings in the greenhouse. The seedlings apparently contracted the virus through seed transmission. Another possibility is that psylla toxin, introduced from heavy psylla feeding, caused the curl. This seems unlikely, however, in view of the experiments herein reported, where high percentages of both exposed- and caged-control trees developed curl, although they were never subjected to more than occasional visitation by adult psylla.

As mentioned previously, a photograph presented by Reimer (1925) showed curl symptoms on an Old Home tree-indicating that curl occurred, at least in this variety, many years before pear psylla were found along the Pacific coast or the advent of pear decline.

\section{Rootstock Recommendations}

Only one consistent significant difference was statistically apparent between trees of any one variety with Bartlett, Winter Nelis, or P. calleryana seedlings, or own-rooted Old Home rootstocks: trees with Bartlett seedling stocks had smaller trunk circumferences. This difference seemed mainly due to the initial disadvantage of smaller nursery trees.

In a further effort to determine the relative merit of each scion-rootstock combination, each type of topgrafted tree in the exposed-control group was scored and ranked according to data in tables 1 to 3 and 5 to 7 . Trees were scored from 1 (lowest merit) to 4 (greatest merit) for survival (1965), trunk circumference and shoot growth (1962 to 1965), percentage of trees with red leaves and red leaf rating (1963 and 1965), and percentage of trees with leaf curl as well as leaf curl rating for Bartlett (1965). (Because Old Home was not used as a rootstock for Hardy, scoring for Hardy trees stopped at 3.) See text table on page 200 for total scores.

Under the conditions of these experiments, $P$. calleryana seedlings and ownrooted Old Home are recommended as about equally good rootstocks for 
VARIETY AND

ROOTSTOCK

\begin{tabular}{ll}
\hline Bartlett & \\
Bartlett seedling & 33 \\
Winter Nelis seedling & 34 \\
P. calleryana seedling & 45 \\
Old Home & 43 \\
Winter Nelis & \\
Bartlett seedling & 31 \\
Winter Nelis seedling & 35 \\
P. calleryana seedling & 46 \\
Old Home & 32 \\
Hardy & \\
Bartlett seedling & 25 \\
Winter Nelis seedling & 32 \\
P. calleryana seedling & 28
\end{tabular}

young Bartlett trees, and both are considered superior to Winter Nelis or Bartlett seedlings. Although considerable interest has been expressed in the relative merits of Bartlett and Winter Nelis seedlings as rootstocks for Bart- lett, our study indicates that one cannot be recommended over the other.

Pyrus calleryana seedlings are recommended as the best stock for young Winter Nelis trees, and there is little preference among the others. It is interesting that Old Home did not prove to be as good stock for Winter Nelis as it was for Bartlett.

Winter Nelis seedlings are recommended as the best rootstocks for young Hardy trees, although the differences in scores were small.

Just as no one rootstock proved best for all three varieties, no one rootstock can be expected to be superior in all of California's pear districts. A combination of these rootstocks is suggested, therefore, with the greatest proportion of trees of one variety having the rootstock or rootstocks that proved best for it.

\section{CONCLUSIONS}

High percentages of survival under all treatments for Bartlett, Winter Nelis, or Hardy trees with Bartlett seedling, Winter Nelis seedling, $P$. calleryana seedling, or own-rooted old Home rootstocks confirmed the decline tolerance of trees with these stocks.

The loss of exposed-control or psyllainfested trees with either $P$. serotina or $P$. ussuriensis rootstocks to pear decline confirmed the decline-susceptibility of $P$. communis trees with these rootstocks. Enclosing trees with these rootstocks with psylla-tight cages protected them from pear decline, corroborating previous reports that the pear psylla is the pear decline vector. Trees with $P$. ussuriensis stocks were more tolerant to psylla feeding and pear decline than those with $P$. serotina stocks, but neither of these species should be used as rootstocks for varieties of $P$. communis in commercial plantings.

Non - topgrafted Bartlett, Winter Nelis, and $P$. calleryana seedlings and the own-rooted Old Home trees showed high percentages of survival, regardless of psylla infestation. Survival was not as high for the non-topgrafted $P$. serotina and $P$. ussuriensis seedlings. Some of the exposed-control $P$. serotina seedlings apparently died of decline, and the decline susceptibility of these trees was verified by increased mortality following psylla infestation. This provided further evidence that trees without graft unions may succumb to decline.

All three varieties with $P$. calleryana seedling rootstocks in the exposed-control group made more trunk and shoot growth during the first two years than similarly treated trees with the other types of rootstocks. This greater initial vigor of trees with $P$. calleryana rootstocks is suggested as advantageous for replants in old orchards. For the remaining three years, differences in growth among trees with the declinetolerant stocks were small. Trees with $P$. serotina and $P$. ussuriensis rootstocks were smaller in trunk circumference and generally made less shoot 
growth than trees with the declinetolerant stocks.

Shoot growth was reduced in psyllainfested trees, but trees with any of the rootstocks except $P$. serotina seedlings made about the same amount of growth during the year after the psylla were removed as did comparable exposed controls. Trunk growth was reduced in surviving trees with $P$. serotina stocks, but it was reduced only slightly or not at all in trees with the other types of rootstocks.

Non-topgrafted trees grew more rapidly and attained greater size than their topgrafted counterparts. Pyrus calleryana trees showed remarkable vigor. Own-rooted Old Home trees were significantly smaller in trunk circumference than the $P$. calleryana trees, but they were significantly larger than the other types. Winter Nelis, Bartlett, $P$. ussuriensis, and $P$. serotina seedlings, in that order, followed next in mean size of trunk.

Vigor of each type of the non-topgrafted rootstock trees was correlated with the amount of vigor and pear decline tolerance each could impart when serving as a rootstock for $P$. communis varieties. The $P$. serotina and $P$. ussuriensis trees were more variable in trunk size and shoot growth than the other types of rootstock trees. Some of the $P$. ussuriensis trees showed great vigor; this may explain how mature trees with these rootstocks show greater resistance to pear decline than trees with $P$. serotina stocks.

Size of the root systems was correlated with the size and vigor of the above-ground portions of the trees. Trunk circumference at the time the trees were pulled gave a better indication of the size of the root system than the amount of shoot growth made during the final growing season. In view of the huge root systems produced by most of the non-topgrafted $P$. calleryana seedlings, and a few of the $P$. ussuriensis seedlings, it was noteworthy that these species, when topgrafted, could not develop appreciably larger root systems than own-rooted Old Home or Winter Nelis and Bartlett seedlings. Although developed from cuttings, the root systems of the own-rooted Old Home trees were well distributedcomparing favorably with root systems of the seedling rootstocks.

Regardless of treatment or type of tree, the most vigorous trees tended to have the least early fall red foliage. Trees infested with psylla during 1962 and 1963 showed increased red foliage on all combinations. Following the removal of the psylla, the trees showed increased growth and less red foliage, but part of the "improvement" of trees with $P$. serotina and $P$. ussuriensis stocks was due to the elimination of trees by pear decline.

The caged-control trees were practically free of red foliage until the cages were removed. This emphasized the role of psylla feeding as the cause of red foliage and indicated that a very light infestation can cause reddening.

Previous reports have assumed that early fall red foliage associated with pear decline is a nonspecific symptom resulting from girdling brought about by necrosis of phloem sieve tubes below the bud union in susceptible scion-stock combinations. In these experiments psylla feeding caused red foliage in non-topgrafted trees and in declinetolerant as well as decline-susceptible scion-stock combinations. It appears, therefore, that girdling is not always a prerequisite to the development of red foliage, and that red foliage may indicate damage from psylla feeding alone or psylla feeding plus pear decline virus for non-topgrafted trees and both decline-tolerant and decline-susceptible scion-stock combinations.

Curl symptoms in exposed-control trees were noted in October, 1965, in from 80 to 100 per cent of Bartlett, Winter Nelis, and Hardy trees with the decline-tolerant rootstocks. Trees with 
$P$. serotina and $P$. ussuriensis stocks showed less curl, suggesting a positive correlation between vigor and curl. A study of individual trees verified this relationship regardless of scion-stock combination or treatment. Evidently, vigorous shoot growth favors the expression of curl symptoms.

A few of the trees that were caged during 1962 and 1963 remained free of curl, indicating that the cages gave some protection against curl by preventing or delaying its transmission by psylla.

Eighty-five per cent of the non-topgrafted Bartlett and 75 per cent of the Winter Nelis seedlings showed curl in the exposed-control group. Since the seed for these came from a number of trees, it seemed more likely that the high incidence of curl resulted from infestation within the nursery or experimental plot rather than from a seedborne virus. In contrast, all of the exposed-control Old Home trees showed curl. This seemed to indicate that the clonally propagated Old Home trees carried curl from the parent trees. Part of the differences in the amount of curl between the two kinds of trees, however, could have been due to the fact that the seedling trees were not as uniform in vigor as the Old Home trees. Also, one of the previously caged Old Home trees was free of curl symptoms and vigorous.

None of the non-topgrafted $P$. calleryana and only a few of the $P$. serotina and $P$. ussuriensis seedlings showed curl. The oriental species of pears may be resistant to the disorder, or perhaps they are symptomless carriers of it. Since the scion varieties showed nearly as high percentages of curl on $P$. cal- leryana as on Old Home, it appears that the rootstock is not a primary factor.

Psylla strains from New York and other sources, presumably free of pear decline virus, apparently induced curl symptoms in young pear trees, suggesting that the two diseases are caused by separate entities.

Psylla are evidently the vectors of curl, and there appears to be little hope of controlling the disease through selection of seed, rootstock, variety, or propagating wood, unless psylla are excluded. If not infected in the nursery row, many pear trees may quickly become infected in the young orchard even under the best commercial spray program.

The study revealed no outstanding differences among trees of one variety with the different decline-tolerant rootstocks. Pyrus calleryana seedlings and own-rooted Old Home are recommended as about equally good rootstocks for young Bartlett trees, and both are considered superior to Winter Nelis or Bartlett seedlings. The performance of Bartletts on either Winter Nelis or Bartlett seedlings was about equal. For Winter Nelis trees, $P$. calleryana seedlings are recommended as the best stock. For Hardy trees, Winter Nelis seedling rootstocks are recommended over $P$. calleryana and Bartlett seedlings, although the differences in scores were small. Old Home was not used as a rootstock for Hardy.

Since no one rootstock can be expected to be superior in all orchard situations, a mixture of the declinetolerant rootstocks is suggested, with the greatest proportion of trees of one variety being propagated on the rootstock or rootstocks recommended as best for it.

\section{ACKNOWLEDGMENTS}

Sincere thanks and appreciation are due C. Q. Gonzales for his assistance with the psylla infestation tests; Henry Schneider and S. M. Gotan for their histological examinations of phloem tis- sue in relation to pear decline; L. R. McKinnon for the photographs; and to J. A. Beutel for assistance with the study of leaf curl. 


\section{LITERATURE CITED}

BatJer, L. P., E. S. Degman, and N. R. Benson

1961. Pear decline trends in Washington orchards. Plant Disease Reporter 45(4) : 255-57.

BATJER, L. P., and H. SCHNEIDER

1960. Relation of pear decline to rootstocks and sieve-tube necrosis. Proc. Amer. Soc. Hort. Sci. 76: 85-97.

Blodgett, E. C., and M. D. Aichele

1960. Behavior of some Bartlett pear trees on their own roots. Plant Disease Reporter 44(6): 438-40.

Blodgett, E. C., M. D. Aichele, and J. L. Parsons

1963. Evidence of a transmissible factor in pear decline. Plant Disease Reporter 47: 89-93.

BlodgetT, E. C., H. SchNeIDER, and M. D. Aichele

1962. Behavior of pear decline disease on different stock-scion combinations. Phytopathology $52(7): 679-84$.

Catlin, P. B., and A. A. Millecan

1967. Diagnoses of pear decline and rootstock identification in young pear orchards. Calif. Agric. 21(7) : 10-11.

DAY, L. H.

1947. Apple, quince, and pear rootstocks in California. Calif. Agric. Exp. Sta. Bul. 700. 44 p.

Gonzales, C. Q., W. H. Griggs, D. D. Jensen, and S. M. Gotan

1963. Orchard tests substantiate role of pear psylla in pear decline. Calif. Agric. 17(1) : 4-6.

Griggs, W. H., and H. T. HARTMANN

1960. Old Home pear trees show resistance to decline when on own roots. Calif. Agric. 14(10): 8-10.

Griggs, W. H., K. Ryugo, R. S. Bethell, and K. UriU

1962. Pear decline research. Calif. Agric. 16(6) : 9-10.

HaRTMAN, $\mathrm{H}$.

1962. Certain investigations pertaining to pear decline in Oregon. Oreg. Agric. Exp. Sta. Special Report $143.52 \mathrm{p}$.

Hartmann, H. T., W. H. Griggs, and C. J. Hansen

1963. Propagation of own-rooted Old Home and Bartlett pears to produce trees resistant to pear decline. Proc. Amer. Soc. Hort, Sci. 82: 92-102.

Jensen, D. D. and W. R. ERwin

1963. The relation of pear psylla to pear decline greenhouse tests. Calif. Agric. 17(1) : 2-3.

Jensen, D. D., W. H. GRigGs, C. Q. Gonzales, and H. Schneider

1964. Pear decline virus transmission by pear psylla. Phytopathology 54(11) : 1346-51.

Millecan, A. A., S. M. Gotan, and Carl W. Nichols

1963. Red-leaf disorders of pear in California. Calif. Dept. of Agric. Bul. 52(3) : 166-70.

Nichols, Carl W., Henry Schneider, H. J. O'Reilly, Thomas A. Shalla and W. H. Griggs 1960. Pear decline in California. Calif. Dept. of Agric. Bul. 49(3) : 186-92.

REIMER, F. C.

1925. Blight resistance in pears and characteristics of pear species and stocks. Oreg. Agric. Exp. Sta. Bul. 214. 99 p.

RYugo, KaY

1963. The apparent reversibility of pear decline by top-grafting to clones of Pyrus serotina (Rehd.). Proc. Amer. Soc. Hort. Sci. 83: 199-204.

SCHNEIDER, H

1959. Anatomy of bud-union bark of pear trees affected by decline. (Abstract). Phytopathology $49(9): 550$.

Shalla, T. A., T. W. Carroll, and L. Chiarappa

1964. Transmission of pear decline by grafting. Calif. Agr. 18(3) : 4-5.

Shalla, T. A., L. Chiarappa, and T. W. Carroll

1963. A graft-transmissible factor associated with pear decline. Pytopathology 53(3): 366-67. 
Tsao, Pamela W., Henry Schneider, and G. H. Kaloostian

1966. A brown leaf-vein symptom associated with greenhouse-grown pear plants infected with pear decline virus. Plant Disease Reporter 50 (4) : 270-74.

Tukey, H. B., and K. D. Brase

1933. Trials with pear stocks in New York. Proc. Amer. Soc. Hort. Sci. 30: 361-64.

WeSTwood, M. N., and P. B. LOMBARD

1966. Pear rootstocks. Annual Report, Oregon State Horticulture Society 58: 61-68.

Westwood, M. N., F. C. ReIMer, and V. L. QUACKenBush

1963. Long term yield as related to ultimate tree size of three pear varieties grown on rootstocks of five Pyrus species. Proc. Amer. Soc. Hort. Sci. 82: 103-13.

Woodbridge, C. G., E. C. BlodgetT, and T. O. Diener

1957. Pear decline in the Pacific Northwest. Plant Disease Reporter 41(7) : 567-72. 
Contrary to previous reports, these experiments showed that girdling from phloem sieve-tube necrosis is not always a prerequisite to the development of red foliage. Also, red foliage may indicate damage from psylla feeding alone or psylla feeding plus pear decline virus for non-topgrafted trees and decline-tolerant scion-stock combinations, as well as decline-susceptible ones.

Leaf curl symptoms occurred in a large percentage of the exposed-control and psylla-infested topgrafted trees, and in non-topgrafted Bartlett and Winter Nelis seedlings, and own-rooted Old Home. Differences in variety, source of scionwood, species or type of rootstock had little effect on incidence of curl. A few of the caged-control trees remained free of curl for more than a year after the cages were removed. This indicated that cages prevented or delayed its transmission by psylla. Psylla strains from New York and other sources, presumably free of pear decline virus, apparently induced curl in young pear trees, suggesting that the two diseases are separate entities. Evidently, complete exclusion of psylla would be required to control curl.

The study revealed no outstanding differences among trees of one variety with the different decline-tolerant rootstocks. A mixture of the decline-tolerant rootstocks is recommended over any single rootstock for commercial plantings of the three varieties studied, however, because no one rootstock can be expected to be superior in all orchard situations. rather than scientific identifications. In so doing it is unavoidable in some cases that similar products which are on the market under other trade names may not be cited. No endorsement of named products is intended nor is criticism implied of similar products which are not mentioned. 
The journal HILGARDIA is published at irregular intervals, in volumes of about 650 to 700 pages. The number of issues per volume varies.

Single copies of any issue may be obtained free, as long as the supply lasts; please request by volume and issue number from:

\author{
Agricultural Publications \\ University Hall \\ University of California \\ Berkeley, California 94720
}

The limit to nonresidents of California is $\mathbf{1 0}$ separate titles. The limit to California residents is 20 separate titles.

The journal will be sent regularly to libraries, schools, or institutions in one of the following ways:

1. In exchange for similar published material on research.

2. As a gift to qualified repository libraries only.

3. On a subscription basis $-\$ 7.50$ a year paid in advance. All subscriptions will be started with the first number issued during a calendar year. Subscribers starting during any given year will be sent back numbers to the first of that year and will be billed for the ensuing year the following January. Make checks or money orders payable to The Regents of The University of California; send payment with order to Agricultural Publications at above address. 